\title{
PAMPATHERIUM HUMBOLDTII (LUND, 1839) (XENARTHRA, CINGULATA) OF THE SOUTHERN BRAZILIAN QUATERNARY: CRANIAL ANATOMY AND TAXONOMIC REMARKS
}

\author{
THAIS MATOS PEREIRA FERREIRA \\ Programa de Pós-Graduação em Geociências, Universidade Federal do Rio Grande do Sul, \\ Av. Bento Gonçalves, 9500, 91501-970, Porto Alegre, RS, Brazil. \\ thaisferreiramp@gmail.com \\ ELVER LUIZ MAYER \\ Programa de Pós-Graduação em Geociências, Universidade Federal do Rio Grande do Sul, \\ Av. Bento Gonçalves, 9500, 91501-970, Porto Alegre, RS, Brazil. \\ elvermayer@gmail.com \\ JORGE FERIGOLO \\ Museu de Ciências Naturais, Fundação Zoobotânica do Rio Grande do Sul, \\ Av. Salvador França, 1427, 90690-000, Porto Alegre, RS, Brazil. \\ jorge-ferigolo@fzb.rs.gov.br \\ JAMIL PEREIRA \\ Museu Coronel Tancredo Fernandes de Mello, Rua Barão do Rio Branco, 467, 96230000, \\ Santa Vitória do Palmar, RS, Brazil. \\ jamil_pereira@terra.com.br \\ ANA MARIA RIBEIRO \\ Museu de Ciências Naturais, Fundação Zoobotânica do Rio Grande do Sul, \\ Av. Salvador França, 1427, 90690-000, Porto Alegre, RS, Brazil. \\ ana-ribeiro@fzb.rs.gov.br
}

\begin{abstract}
This work presents a new specimen of Pampatheriidae, which consists of a skull without the rostrum. The fossil comes from an outcrop along the Chuí Creek, Santa Vitória do Palmar Municipality, Rio Grande do Sul State (RS), Brazil. It was found in a sedimentary layer of the Lagoon System III, of $40 \mathrm{~cm}$ thickness and consisting predominantly of fine sand and up to 20-25\% silt and clay, together with other vertebrate and invertebrate fossils, some of which are related to the mammalian taxa of the Late Pleistocene of the Pampean Region of Buenos Aires Province, Argentina, of Lujanian age. The comparison of the material with the Quaternary Brazilian pampatheres from the Lagoa Santa region, Minas Gerais; Jacobina, Bahia; and Rio Madeira, Rondônia; as well as with those from Uruguay and Argentina, permits the assignment of the specimen to Pampatherium humboldtii (Lund). The specimen represents the first cranial material of this species described from RS, as up until now $P$. humboldtii was represented mainly by isolated osteoderms. In addition, a preliminary revision of the Pampatheriidae material from the P.W. Lund Collection is presented.
\end{abstract}

Keywords: Pampatheriidae, Chuí Creek, Lagoon System III, Lagoa Santa, Late Pleistocene, Brazil.

RESUMO - O presente trabalho apresenta novo material de Pampatheriidae, que consiste em um crânio sem a porção rostral. O fóssil foi coletado em um afloramento ao longo do Arroio Chuí, Município de Santa Vitória do Palmar, Rio Grande do Sul (RS), Brasil. Ele foi encontrado em uma camada sedimentar do Sistema Lagunar III, com $40 \mathrm{~cm}$ de espessura e formada predominantemente por areia fina e até $20-25 \%$ de silte e argila, juntamente com outros fósseis de vertebrados e invertebrados, sendo que alguns táxons de mamíferos são afins com aqueles do Pleistoceno final da Região Pampeana da Província de Buenos Aires, Argentina, de idade Lujanense. A comparação do material com os pampaterídeos pleistocênicos brasileiros, procedentes da região de Lagoa Santa, Minas Gerais; Jacobina, Bahia; e Rio Madeira, Rondônia; assim como do Uruguai e Argentina, permitiu atribuir o espécime a Pampatherium humboldtii (Lund). O espécime representa o primeiro material craniano de $P$. humboldtii descrito para o RS, visto que até o presente momento a espécie estava representada no estado principalmente por osteodermos isolados. Além disso, uma revisão preliminar do material de Pampatheriidae da Coleção P.W. Lund é apresentada.

Palavras-chave: Pampatheriidae, Arroio Chuí, Sistema Lagunar III, Lagoa Santa, Neopleistoceno, Brasil. 


\section{INTRODUCTION}

Xenarthra is a superorder of placental mammals that diversified during the Paleogene following the separation of South America and Africa (about 80-65 Ma), which resulted in the relative isolation of the South American continent, since there was still a connection with Antarctica (Delsuc et al., 2004 and references therein; Reguero et al., 2014). The age estimated by molecular data for the xenarthran crown group is about 55-75 Ma, which even suggest that the clade had its origin around $105 \mathrm{Ma}$ considering an existence of a ghost lineage for around $50 \mathrm{Ma}$, since the xenarthrans are first recorded in the fossil record at $58 \mathrm{Ma}$, at the beginning of the Cenozoic (Delsuc et al., 2004). Xenarthrans include armadillos (Cingulata), anteaters (Pilosa, Vermilingua) and sloths (Pilosa, Folivora), with living and extinct representatives (McKenna \& Bell, 1997). They present a variety of habits: cursorial, fossorial, excavator, semiarboreal, arboreal and terricolous (Gaudin, 1999). The group is considered monophyletic and is recognized by, for example, the presence of accessory joints in the vertebrae, ischiosacral fusion and dental simplification, including the loss of enamel (Engelmann, 1985). Possible exceptions would be the armadillos Utaetus buccatus Ameghino, 1902, Astegotherium dichotomus Ameghino, 1902 and Dasypus Linnaeus, 1758, which have enameled dental portions (Simpson, 1932; Ciancio et al., 2014).

The order Cingulata includes living and extinct species that are grouped into the Dasypodoidea, which includes Peltephilidae and Dasypodidae; and the Glyptodontoidea, which comprises Glyptodontidae, Palaeopeltidae and Pampatheriidae (McKenna \& Bell, 1997; but see Gibb et al., 2015; Delsuc et al., 2016). Pampatheriidae is recorded from the Middle Miocene to the early Holocene, and its geographic distribution ranges from Argentina to the United States of America (Scillato-Yané et al., 2005; Góis et al., 2012). The expansion of the pampatheres to North American regions is known to have occurred during two events: before the total uplift of the Isthmus of Panama at 3.7 Ma ago, as recorded in México; and later, with the $25 \mathrm{~m}$ decrease in sea level at 2.4 Ma ago, as recorded in the United States of America, which represents the first dispersion event of the Great American Biotic Interchange (GABI) (Woodburne, 2010). Currently, the taxa considered valid for the family Pampatheriidae include four genera recorded for the Neogene (Scirrotherium Edmund \& Theodor, 1997, Kraglievichia Castellanos, 1927, Vassallia Castellanos, 1927 and Plaina Castellanos, 1937) and three genera for the Quaternary (Pampatherium Gervais \& Ameghino, 1880, Holmesina Simpson, 1930 and Tonnicinctus Góis, GonzálezRuiz, Scillato-Yané \& Soibelzon, 2015). Pampatheres are characterized by the presence of robust and tall mandibles; a dental formula of 9/9; oval or elliptical anterior teeth; bior trilobate posterior teeth; the first or the first two upper teeth implanted in the premaxilla; short-nailed phalanges of the feet; and osteoderms composing the cephalic, scapular, pelvic and caudal shields. The carapace shield is composed by immovable, hexa- or pentagonal osteoderms that are separated by three bands of quadrilateral movable osteoderms (Paula Couto, 1979, 1980).

The species of Pampatheriidae identified for the Quaternary are: Pampatherium humboldtii (Lund, 1839), $P$. typum Gervais \& Ameghino, 1880, P. mexicanum Edmund, 1996, Holmesina major (Lund, 1842), H. septentrionalis (Leidy, 1889), H. occidentalis (Hoffstetter, 1952), H. floridana (Robertson, 1976), H. paulacoutoi (Cartelle \& Bohórquez, 1985), H. rondoniensis Góis, Scillato-Yané, Carlini \& Ubilla, 2012 and Tonnicinctus mirus Góis, González-Ruiz, Scillato-Yané \& Soibelzon, 2015. The record of pampatheres in the Quaternary of South America shows that the group inhabited areas that today correspond to Argentina, Brazil, Bolivia, Colombia, Ecuador, Paraguay, Peru, Venezuela and Uruguay (Góis et al., 2012 and references therein; Góis, 2013; Figure 1). In Brazil, the reported species are: $P$. humboldtii, $P$. typum, H. major, H. paulacoutoi, H. rondoniensis and Tonnicinctus mirus, which are distributed across 11 Brazilian states (Table 1; Figure 1). Furthermore, Avilla et al. (2013) and Pansani et al. (2016) presented records at a generic level for the states of Tocantins (Pampatherium sp.) and Mato Grosso do Sul (Holmesina sp.), respectively.

Fossils of Quaternary pampatheres are mostly represented by dentaries, teeth and postcranial elements, mainly osteoderms of the cephalic, carapace and caudal shields (Góis, 2013 and references therein). Cranial elements are not common, but in South America they have been found in Argentina, Ecuador, Uruguay and Brazil (Table 2). In relation to the South of Brazil, particularly in the State of Rio Grande do Sul, the Quaternary pampatheres are represented essentially by osteoderms found in different localities: Touro Passo Creek (Touro Passo Formation, Uruguaiana Municipality), Ibicuí River (Sanga da Cruz, Alegrete Municipality), the Sanga dos Borba locality (Pantano Grande Municipality), as well as the Coastal Plain of Rio Grande do Sul, Lagoa Mangueira and Chuí Creek (Ribeiro \& Scherer, 2009).

For one of the localities along the Chuí Creek (Santa Vitória do Palmar Municipality), Pereira (2014) mentioned the discovery of a cranial specimen, attributed to Pampatherium sp., which was found along with osteoderms and fossils of other Pleistocene mammals. Considering that this is the only Pampatheriidae cranial material reported for Rio Grande do Sul to date, it is of great importance to the study of this family. The present contribution aims to describe in detail this cranial material to refine its taxonomic identification, and to present a comparative analysis in order to clarify aspects of certain anatomical characters that are important for the differentiation of taxa within the family. In addition, we present taxonomic remarks about some specimens from the P.W. Lund Collection, recovered from the Lagoa Santa region, Minas Gerais, Brazil, mainly regarding the specimen proposed as the lectotype of the species Pampatherium humboldtii. 

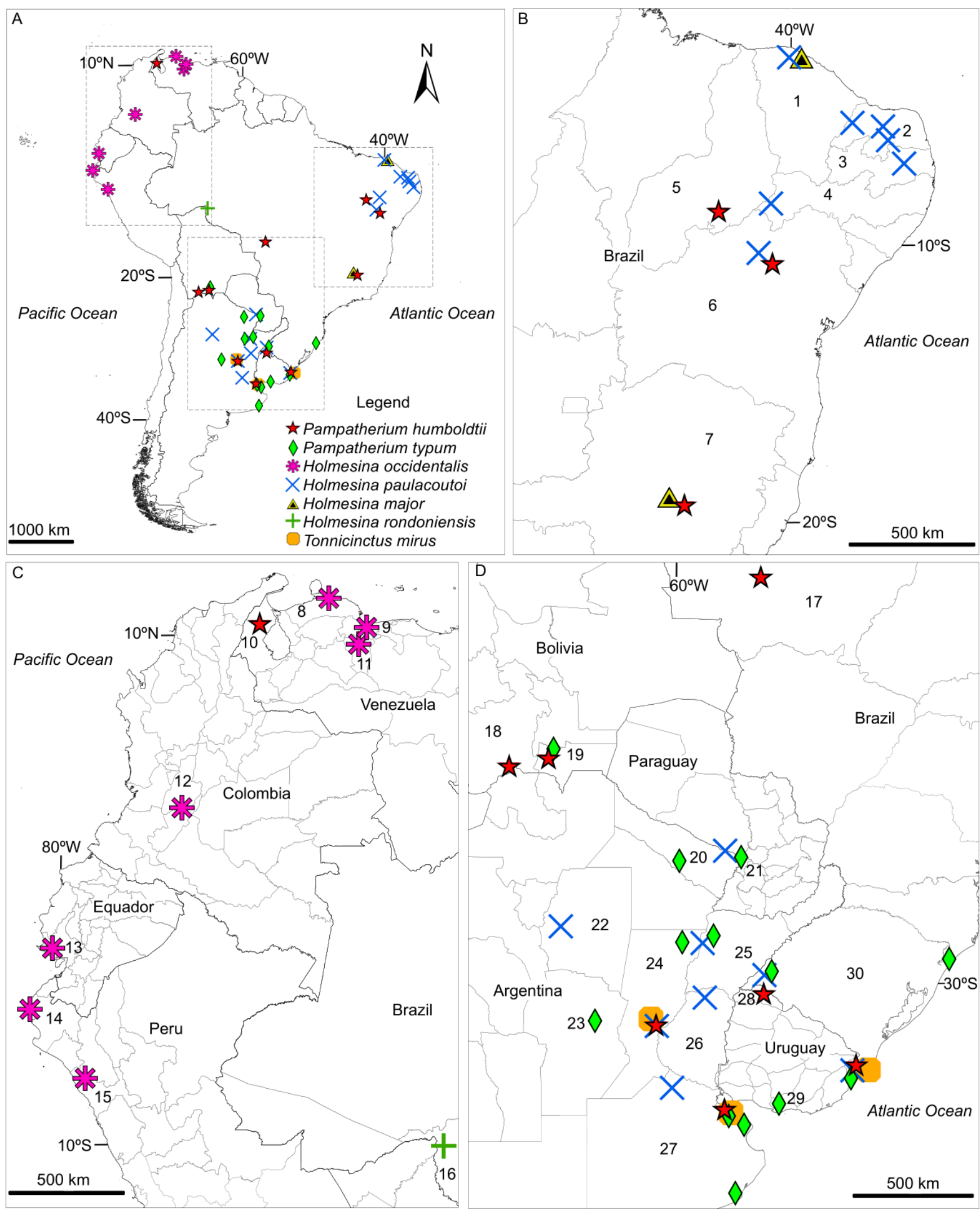

Figure 1. A, Geographic distribution map of the records of the family Pampatheriidae in the Quaternary of South America. B-D, approximate location given: 1, Ceará State; 2, Rio Grande do Norte State; 3, Paraíba State; 4, Pernambuco State; 5, Piauí State; 6, Bahia State; 7, Minas Gerais State; 8, Falcón State; 9, Carabobo State; 10, Zylia State; 11, Cojedes State; 12, Hulia State; 13, Santa Elena Province; 14, Piura Región; 15, Cajamarca Región; 16, Rondônia State; 17, Mato Grosso State; 18, Potosí Departament; 19, Tarija Departament; 20, Formosa Province; 21, Asunción Departament; 22, Santiago del Estero Province; 23, Córdoba Province; 24, Santa Fé Province; 25, Corrientes Province; 26, Entre Ríos Province; 27, Buenos Aires Province; 28, Artigas Departament; 29, Canelones Departament; 30, Rio Grande do Sul State. Data source: GADM. 
Table 1. Record of species of Pleistocene pampatheres in Brazilian states.

\begin{tabular}{|c|c|c|}
\hline State & Taxon & References \\
\hline Bahia & $\begin{array}{l}\text { Pampatherium humboldtii } \\
\text { Holmesina paulacoutoi }\end{array}$ & $\begin{array}{c}\text { Cartelle (1992) } \\
\text { Cartelle \& Bohórquez (1985); Cartelle (1992) }\end{array}$ \\
\hline Ceará & $\begin{array}{l}\text { H. paulacoutoi } \\
\text { H. major }\end{array}$ & $\begin{array}{c}\text { Gomide (1989); Bergqvist et al. (1997); Cartelle (1992); } \\
\text { Edmund (1996) }\end{array}$ \\
\hline Mato Grosso & P. humboldtii & Cartelle (1992) \\
\hline Minas Gerais & $\begin{array}{l}\text { P. humboldtii } \\
\text { H. major }\end{array}$ & $\begin{array}{l}\text { Lund (1839) } \\
\text { Lund (1842) }\end{array}$ \\
\hline Paraíba & H. paulacoutoi & Bergqvist et al. (1997) \\
\hline Pernambuco & H. paulacoutoi & Silva et al. (2010) \\
\hline Piauí & P. humboldtii & Guérin \& Faure (2008) \\
\hline Rio Grande do Norte & H. paulacoutoi & Santos et al. (1990); Oliveira \& Santos (1990); Porpino et al. (2004) \\
\hline Rondônia & H. rondonienses & Góis et al. (2012) \\
\hline Santa Catarina & P. typum & Paula Couto (1980) \\
\hline Rio Grande do Sul & $\begin{array}{l}\text { P. humboldtii } \\
\text { P. typum } \\
\text { H. paulacoutoi } \\
\text { Tonnicinctus mirus }\end{array}$ & $\begin{array}{c}\text { Bombim (1976); Oliveira \& Pereira (2009) } \\
\text { Oliveira (1996); Kerber \& Oliveira (2007, 2008); } \\
\text { Oliveira (1996); Oliveira \& Pereira (2009); Pereira (2014) } \\
\text { Ferreira et al. (2017) }\end{array}$ \\
\hline
\end{tabular}

Table 2. Pampatheriidae cranial specimens from the Pleistocene of Argentina, Brazil and Uruguay.

\begin{tabular}{|c|c|c|c|}
\hline Specie & Cranial specimen & Fossiliferous locality & References \\
\hline \multirow{3}{*}{$\begin{array}{l}\text { Pampatherium humboldtii } \\
\text { (Lund, 1839) }\end{array}$} & $\begin{array}{l}\text { ZMK 1/1845: } 2314 \\
\text { ZMK 1/1845: } 2318\end{array}$ & $\begin{array}{l}\text { Lapa do Baú, Lagoa Santa, } \\
\text { Minas Gerais, Brazil }\end{array}$ & Lund (1839a); Winge (1915) \\
\hline & MHD-P-28 & $\begin{array}{l}\text { Formação Sopas, Rincón de } \\
\text { Pintado, Uruguay }\end{array}$ & $\begin{array}{c}\text { Ubilla }(1985,1996) \text {; Tambusso \& } \\
\text { Fariña (2015) }\end{array}$ \\
\hline & MLP 81-X-30-1 & $\begin{array}{l}\text { Berazategui, Provincia de } \\
\text { Buenos Aires, Argentina }\end{array}$ & Góis et al. (2012a) \\
\hline \multirow{2}{*}{$\begin{array}{c}\text { Pampatherium typum } \\
\text { Gervais \& Ameghino, } 1880\end{array}$} & MACN PV 11543 (holotype) & Santa Fé, Argentina & $\begin{array}{l}\text { Bordas (1939); De Iullis et al. } \\
\text { (2001) }\end{array}$ \\
\hline & MG-PV 666 & Santa Fé, Argentina & Góis (2013) \\
\hline $\begin{array}{c}\text { Holmesina paulacoutoi } \\
\text { (Cartelle \& Bohórquez, 1985) }\end{array}$ & MCL-501/01 (holotype) & $\begin{array}{l}\text { Gruta das Onças, Jacobina, } \\
\text { Bahia, Brazil }\end{array}$ & Cartelle \& Bohórquez (1985) \\
\hline $\begin{array}{c}\text { Holmesina rondoniensis } \\
\text { Góis, Scillato-Yané Carlini \& Ubilla, } 2012\end{array}$ & MERO-P-002 (holotype) & Rio Madeira, Rondônia, Brazil & Góis et al. (2012b) \\
\hline $\begin{array}{l}\text { Holmesina occidentalis } \\
\text { Hoffstetter, } 1952\end{array}$ & ROM 3381 & El Coralito, Ecuador & Cartelle (1992) \\
\hline $\begin{array}{c}\text { Tonnicinctus mirus } \\
\text { Góis, González Ruiz, Scillato-Yané \& Soibelzon, } 2015\end{array}$ & MLP 54-III-16-1 (holotype) & $\begin{array}{l}\text { Ensenada, La Plata, Buenos } \\
\text { Aires, Argentina }\end{array}$ & Góis et al. (2015) \\
\hline
\end{tabular}

\section{BRIEF NOMENCLATURAL AND TAXONO- MIC HISTORY OF PAMPATHERIIDAE}

In South America, the first remains of Pampatheriidae were described by Peter Lund from the region of Lagoa Santa, State of Minas Gerais, Brazil. The genus Chlamydotherium was presented by Lund (1839a, "Second Memoir of the Fauna in the Caves of Lagoa Santa"), with concurrent proposition of the species $C$. humboldtii and C. giganteum. The species were proposed based on cranial and postcranial bones; however, for the species $C$. giganteum, only one tooth was figured (Lund, 1839a, pl. 2, figs. 4 and 5). The differentiation between these two species was mainly based on the size of the specimens and on the morphology of the dental series. Later, in his "Third Memoir", Lund (1840) reported a left dentary [ZMK 618, "Lapa do Baú" locality] assigned to
C. humboldtii. In a subsequent contribution, Lund (1839b, this work was developed after that published in 1840, but it was published earlier) did not present new material for the genus, but compared the characters observed in C. humboldtii with those of Euphractus specimens, an extant dasypodid armadillo, and with Megalonyx, an extinct ground sloth from the Megalonychidae family. Subsequently, Lund (1842) in his "Fourth Memoir" reported that the fossil specimens used to propose the species $C$. giganteum in fact represent two distinct species. Part of the material (the molariform figured in Lund, 1839a, pl. 2, figs. 4 and 5) corresponded to a giant ground sloth named by him as Ocnotherium gigas [= Glossotherium robustum (Owen, 1842), according to Paula Couto, 1950; note 373], whereas the other specimens were considered to pertain to a new species described by Lund as C. majus Lund, 1842, no longer using the designation " $C$. giganteum". According to Lund (1842), C. majus is distinguished from C. humboldtii 
only by its larger size. Finally, in the "Fifth Memoir", Lund (1843) listed the species he had identified by locality for the Lagoa Santa region and indicated that in Lapa do Baú only C. humboldtii was recorded, while in Lapa da Lagoa do Sumidouro and in Lapa Vermelha, besides $C$. humboldtii, the species C. majus was also recorded.

In 1880, Gervais \& Ameghino considered the genus Pampatherium to be synonymous with Chlamydotherium, including the material found in Argentina attributed to Pampatherium typus (sic), acknowledging, then, three species for the genus: C. humboldtii, C. majus and C. typus. The genus Pampatherium was named by Ameghino (1875), but the work was lost or not even published (see Góis et al., 2012, p. 212) and, therefore, Gervais \& Ameghino (1880) are considered the authors of this genus. Later, Ameghino (1891) detected some nomenclatural mistakes: (i) Lund (1839a), while defining Chlamydotherium, did not realize that this name had already been pre-occupied by a glyptodont defined by Bronn (1838); (ii) Öersted (1839), in a summary of the material sent to Denmark by Lund, misspelled the genus name, naming it Chlamytherium. Öersted's summary (1839) was published before Lund's (1839a), which led some authors (e.g. Paula Couto, 1950; Guth, 1961) to consider Chlamytherium Lund, 1838 as correct. Ameghino (1891) formally synonymized the names Chlamytherium and Chlamydotherium with Pampatherium.

Without taking into consideration Ameghino's synonyms (1891), Winge (1915) revised and figured material collected and studied by Lund (1839a,b, 1840, 1842, 1843), considering valid the term Chlamydotherium and attributing all the specimens of pampatheres studied by Lund $(1839 a, b)$ to a single species, C. majus, thus putting aside C. humboldtii, the first name designated by Lund (1839a). Among the various cranial and postcranial elements attributed to and figured as $C$. majus by Winge (1915, pl. 10) are the skull ZMK 1/1845:2314 and 2318 and the left dentary ZMK 618 (proposed by Lund, 1839a,b, to be C. humboldtii), which are of special interest in the present study.

Concurrent to the studies in South America, in North America, specimens of cingulates from Florida, United States of America, were first studied by Leidy (1889a) and named Glyptodon septentrionalis. However, in the same year, Leidy (1889b) changed his classification and considered the specimens to pertain to Chlamytherium humboldtii, a designation followed by other authors (e.g. Hay, 1902). Later, Sellards (1915), based on new material, proposed a new combination, Chlamytherium septentrionalis, accepted by other authors (e.g. Cahn, 1922; Hay, 1926). Simpson (1930), revising the material from Florida, proposed the genus Holmesina for the fossils of pampatheres found in North America, thus referring them to Holmesina septentrionalis (Leidy, 1889a).

Hoffstetter (1952) defined as Chlamytherium occidentale the fossils of pampatheres from Ecuador, later considering them as Holmesina occidentalis in Hoffstetter (1953). Castellanos (1957) proposed the genus Hoffstetteria to include the species from Ecuador, but later Edmund (1996) returned them to the genus Holmesina. Robertson (1976) defined other fossil remains of Florida pampatheres as Kraglievichia floridanus, which were later designated by Edmund (1987) as Holmesina floridana, representing the oldest pampatheres for the Quaternary of the United States, with findings in the upper Pliocene.

The taxonomic history of pampatheres meanwhile continued in the studies of South American material. Cartelle \& Bohórquez (1985) defined fossils from the State of Bahia, Brazil, as Pampatherium paulacoutoi, later synonymized to Holmesina paulacoutoi (Edmund, 1987; Cartelle, 1992). Edmund (1996) considered H. paulacoutoi as H. occidentalis, but it was not accepted by Cartelle (1992), because, according to the author, the fossils from Bahia present cranial differences that distinguish them from the Ecuadorian material. In the same work, Edmund (1996), through his study of the P.W. Lund Collection, considered valid the species Pampatherium humboldtii (Lund, 1839a), and, from a batch of osteoderms (ZMK 1807), presented a new combination: Holmesina majus (Lund, 1842), whoose genus was previously proposed to encompass the North American pampatheres (Simpson, 1930). Additionally, Edmund (1996) proposed P. mexicanum, a new species for Mexico, based on carapace osteoderms.

Recently, Góis et al. (2012) described two new species: Holmesina rondoniensis, from the Upper Pleistocene of the State of Rondônia, Brazil, and Tonnicinctus mirus, from Ensenada (Lower-Middle Pleistocene), Buenos Aires Province, Argentina (Góis et al., 2015). The latter is the most recent pampathere species described for South America.

\section{GEOLOGICAL, GEOMORPHOLOGICAL AND STRATIGRAPHIC CONTEXT}

The geographic area from which the fossil material under study was recovered is the Coastal Plain of Rio Grande do Sul State (CPRS), Brazil, which is $620 \mathrm{~km}$ long and lies between latitudes $29^{\circ} 18^{\prime} 31^{\prime \prime S}$ and $33^{\circ} 43^{\prime} 17^{\prime \prime} \mathrm{S}$. The CPRS consists of the most recent sedimentary records of the Pelotas Basin (Barboza et al., 2009), a marginal basin located in the southernmost part of Brazil. According to the current definition, the CPRS is divided into two types of distinct depositional systems: the alluvial fans of the Neogene and the four Barrier-Lagoon Systems (I-IV) of the Quaternary (Villwock et al., 1986; Villwock \& Tomazelli, 1995; Tomazelli et al., 2000; Lopes et al., 2014a; Lopes et al., 2016).

Formerly, three different formations for the CPRS were lithostratigraphically defined: the Graxaim, Chuí and Itapoã formations, corresponding to the alluvial fan, marine and wind deposits, respectively (Delaney, 1965; Villwock et al., 1986; Lopes et al., 2016). Soliani (1973) defined as the Santa Vitória Formation the lagoon deposits found between the Chuí and Itapoã formations, in the southern part of the CPRS, in outcrops along the Chuí Creek, explaining that the sediments had derived from the erosion, transportation and redeposition in lagoonal areas of the marine sands exposed soon after marine regressions. Nowadays, this formation is considered to correspond to the Barrier II marine facies (Pereira, 2014 and references therein). 


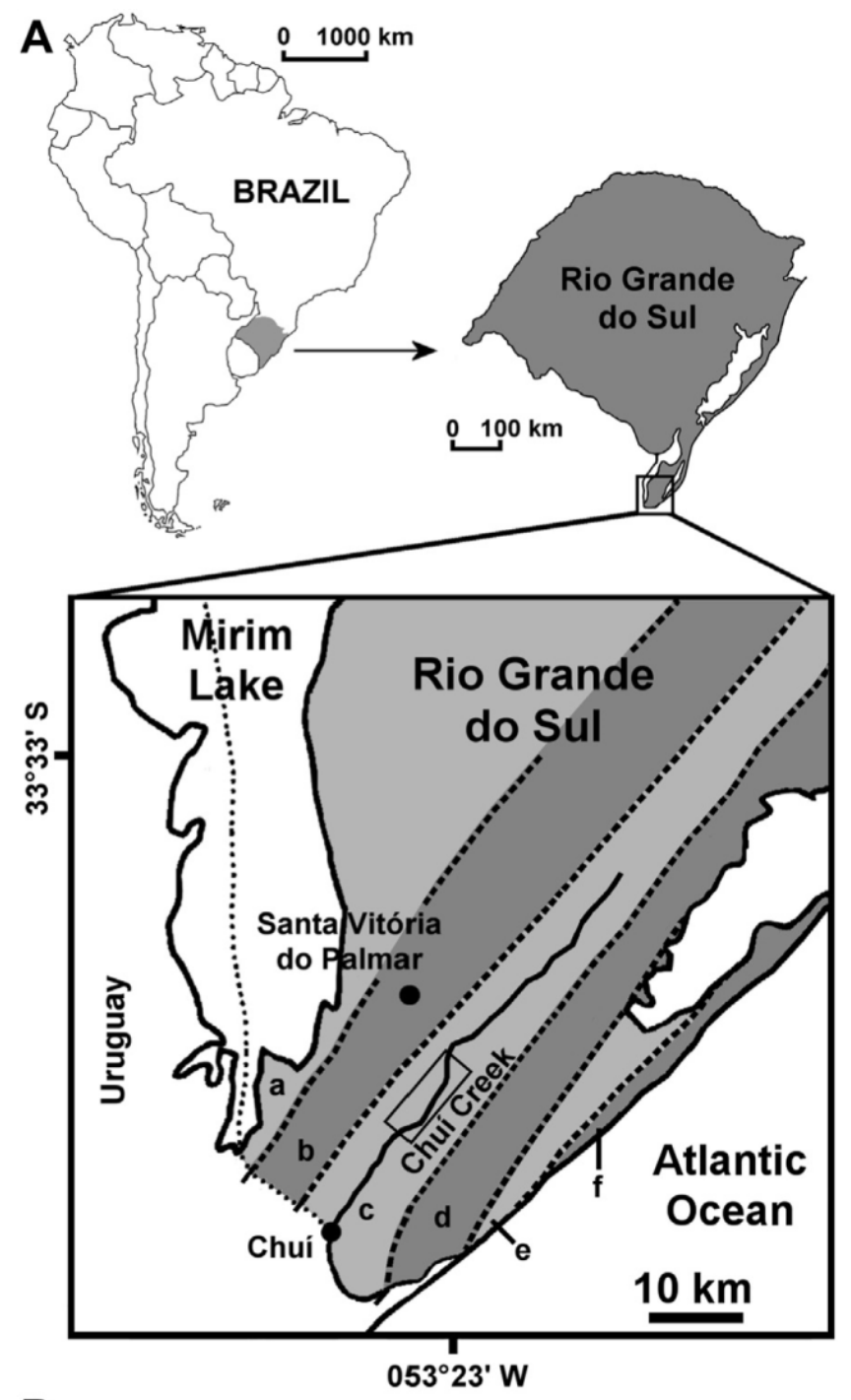

B

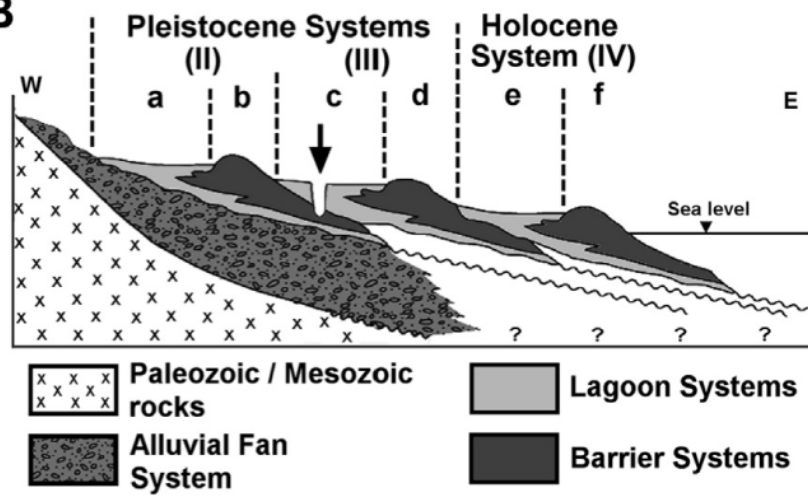

Figure 2. A, geographic location of Chuí Creek, Santa Vitória do Palmar Municipality, Rio Grande do Sul State. B, schematic model of the structure of the Coastal Plain of Rio Grande do Sul (Lopes et al., 2014b).

Following a geological context review of the CPRS, the latter was interpreted as a group of units in accordance with the chronostratigraphy, depositional systems and their respective sedimentary facies. The Neogene alluvial fan system encompasses all facies formed by gravitational flows and alluvial processes, and is located within the CPRS. The sediments of the alluvial fans derive from the igneous and metamorphic rocks of the Precambrian Shield and from the sedimentary and volcanic rocks of the Paraná Basin. The deposition of these sediments initiated during the marine regression in the final Pliocene, and continued throughout the Quaternary, taking into account that the cyclical changes between humid and arid conditions were controlling factors on depositional intensity (Tomazelli et al., 2000; Tomazelli $\&$ Villwock, 2005). The reworking of the terrigenous clastic sediments of the alluvial fans has generated four barrier systems, including the current coastline (Tomazelli et al., 2000; Lopes et al., 2016).

The Barrier-Lagoon I, II, III and IV depositional systems (Figure 2B) were formed by marine transgressions and regressions caused by glacial-eustatic cycles starting 400,000 years ago, with each barrier recording a transgressiveregressive cycle. During the Quaternary, changes also occurred in the patterns of atmospheric circulation and latitudinal displacement (Tomazelli \& Villwock, 2005; Lopes et al., 2014a), indicating that it was a period of intense transformation in the region. Barrier-Lagoon Systems I, II and III formed in the Pleistocene, and IV formed in the Holocene. In order to estimate the ages of each system, the Barriers I, II, III and IV were correlated to the marine isotope stages $11(\sim 400 \mathrm{Ka}), 9(\sim 325 \mathrm{Ka}), 5(\sim 125 \mathrm{Ka})$ and 1 (in progress since $\sim 6 \mathrm{Ka}$ ), respectively (Suguio et al., 1985; Villwock \& Tomazelli, 1995; Tomazelli et al., 2000; Lopes et al., 2014a). An additional stratigraphic study correlated marine isotope stage $7(\sim 220 \mathrm{Ka})$ with Barrier II, generating new data concerning the amplitude and chronology of the rise of the sea level responsible for the origin of the depositional system II. Thus, the age of Barrier II began to be considered as $~ 220$ Ka (Lopes et al., 2014a, 2016), and the estimated age for Barrier III is approximately $\sim 120 \mathrm{Ka}$ (Buchmann et al., 2009).

In the region of Santa Vitória do Palmar (Figures 2A, B), in the southern part of the CPRS, the Barrier-Lagoon Systems I, II, III and IV are found. The Lagoon Systems II and IV are superimposed, respectively, by the Mirim and Mangueira lagoons, while the Lagoon System III is exposed as lowlands, in which the Chuí Creek outcrops can be accessed (Pereira et al., 2012; Lopes et al., 2016). The Chuí Creek cross-cuts the Lagoon System III and encounters Barrier II in the lowest exposed sedimentary layer (Figure 2B). The fossiliferous layer of the Lagoon System III in the outcrop from which the pampathere skull was retrieved is $40 \mathrm{~cm}$ thick, and composed predominantly of fine sand sediment, with up to $20-25 \%$ silt and clay (Lopes, 2013; Lopes et al., 2016). The outcrop preserves important records of invertebrate and vertebrate fossils, including Pleistocene mammals that represent a mixed fauna, with Pampean and intertropical taxa occurring in the same assemblages (Oliveira, 1999; Lopes et al., 2005; Oliveira et al., 2005; Ribeiro \& Scherer, 2009; Oliveira \& Pereira, 2009; Pereira et al., 2012). Due to the presence of mammalian taxa that are very similar to those of the Late Pleistocene of the Pampean Region of Buenos Aires Province, in Argentina, such as native South American ungulates (Toxodon, Macrauchenia), xenarthrans (Megatheriidae Megatherium, 
Mylodontidae Mylodon, Glyptodontidae Glyptodon) and holarctic ungulates (Cervidae Antifer and Morenelaphus; Tayassuidae Catagonus), of Lujanian land-mammal age, as well as the geographic proximity of Rio Grande do Sul and the Pampean Region, the same land-mammal age is also suggested for this outcrop.

\section{MATERIAL AND METHODS}

The studied material consists of a partially fragmented skull belonging to the family Pampatheriidae, and is deposited in the Coronel Tancredo Fernandes de Melo Museum, Santa Vitória do Palmar Municipality, Rio Grande do Sul State, Brazil, under the catalog number MCTFM-PV 0861. According to Pereira (2014), the specimen was recovered from the bank of the Chuí Creek at a location $6 \mathrm{~km}$ from Santa Vitória do Palmar Municipality, between the coordinates UTM $282693 \mathrm{E} / 6280360 \mathrm{~N}$ and $263383 \mathrm{E} / 6282621 \mathrm{~N}$. Pereira (2014) noted the type-section of the sedimentary sequence crops out at the coordinates $282726 \mathrm{E} / 6280605 \mathrm{~N}$, which is within the Lagoon System III (Figure 2B). The fossiliferous layer is at the level of the brown-colored lenticular fluvial deposit above the marine sands and is constituted by fine sand rich in organic matter.

Other materials studied for a preliminary review were pampathere specimens from the P.W. Lund Collection, Zoologisk Museum, Copenhagen, Denmark, designated by the numbers ZMK 618, ZMK 1/1845:2314 and ZMK 1/1845:2318.

The morphological comparative analysis used cranial specimens of various taxa from the Quaternary of South America that are deposited in different scientific collections: Holmesina paulacoutoi (holotype, MCL-501/01), H. rondoniensis (holotype, MERO-P-002), Pampatherium humboldtii (ZMK 1/1845: 2314/2318 and MHD-P-28) and P. typum (holotype, MACN PV 11543). The following bibliographic references were used to describe the comparative material referred to above: Winge (1915), Bordas (1939), Cartelle \& Bohórquez (1985), Ubilla (1996) and Góis et al. (2012). The specimens MCL-501/01, ZMK 1/1845: 2314 and ZMK 1/1845: 2318 were directly studied in their scientific collections, MCL and ZMK, whereas information on other specimens (MHD-P-28; MERO-P-002; MACN PV 11543) was obtained exclusively from specialized literature. To obtain the measurements (given in mm), a Mitutoyo caliper was used. Institutional abbreviations: MACN, Museo Argentino de Ciencias Naturales "Bernardino Rivadavia", Colección Nacional Ameghino and Colección Paleovertebrados, Ciudad de Buenos Aires, Argentina; MCL, Coleção de Paleontologia do Museu de Ciências Naturais da Pontifícia Universidade Católica de Minas Gerais, Belo Horizonte, MG, Brazil; MCN-PV, Coleção da seção de Paleontologia do Museu de Ciências Naturais, Fundação Zoobotânica do Rio Grande do Sul, Porto Alegre, RS, Brazil; MCTFM-PV, Coleção Paleomastozoológica do Museu Coronel Tancredo Fernandes de Melo, Santa Vitória do Palmar, RS, Brazil; MERO, Museu Estadual do Estado de Rondônia, Porto Velho, RO, Brazil;
MG-PV, Museo Provincial de Ciencias Naturales "Florentino Ameghino", Santa Fe, Argentina; MHD-P, Museo Histórico Departamental de Artigas, Artigas, Uruguay; MLP, Museo de La Plata, Facultad de Ciencias Naturales and Museo, Universidad Nacional de La Plata, La Plata, Buenos Aires, Argentina; ROM, Royal Ontario Museum, Toronto, Canada; ZMK, Zoologisk Museum, Copenhagen, Denmark.

\section{SYSTEMATIC PALEONTOLOGY}

\author{
XENARTHRA Cope, 1889 \\ CINGULATA Illiger, 1811 \\ PAMPATHERIIDAE Paula Couto, 1954
}

Pampatherium Gervais \& Ameghino, 1880

Type species. Pampatherium humboldtii (Lund, 1839) Ameghino, 1891.

\section{Pampatherium humboldtii (Lund, 1839)}

(Figure 3)

Lectotype. ZMK 618, left dentary (Lund, 1840, pl. 14, fig. 1; 1842, pl. 34, fig. 9; Winge, 1915; pl. 10; Cartelle, 1992, p. 138).

Described material. MCTFM-PV 0861, incomplete skull (Figure 3).

Geographical and stratigraphic location. Lagoon System III, Chuí Creek, Santa Vitória do Palmar Municipality, Rio Grande do Sul State, Brazil. Upper Pleistocene (Figure 2).

Description. The skull under study (MCTFM-PV 0861) is fragmented, with the absence of part of the rostral portion, zygomatic arches, pterygoids and tympanic rings. There is no associated mandible.

Dorsal view (Figure 3A): The premaxilla, the nasal and the lacrimal bones were not preserved in the specimen; however, it is possible to observe the shape of the nasofrontal suture (Nfs) that remains intact, highlighting a disarticulation of the osseous elements and not a fracture. The shape of the suture is similar to that of the letter "W" and the central elevation corresponds to the articulation for the internasal apophysis of the frontal. The region at the border between the frontals $(\mathrm{Fr})$ and the parietals is fragmented. The anteroposterior length of the frontals is estimated to be approximately 110.0 $\mathrm{mm}$, at the level of the midline of the skull. The interfrontal suture is imperceptible in the specimen. It is also possible to estimate the anteroposterior length of the parietals, at the level of the interparietal suture, to be approximately $80.0 \mathrm{~mm}$, with the inclusion of the portion of the lambdoidal crest in the presented measurement. The lambdoidal crest presents a slight roughness and is short, being $15.87 \mathrm{~mm}$ long. The width at the level of the mandibular fossae is $110.52 \mathrm{~mm}$ and at the level of the postorbital constriction is $71.29 \mathrm{~mm}$; therefore, the parietals are wide. The parietals present many vascular foramina, distributed between this and the squamous portion of the temporal, there being 22 foramina on the left side and 20 foramina on the right side. The sagittal crest, formed over 


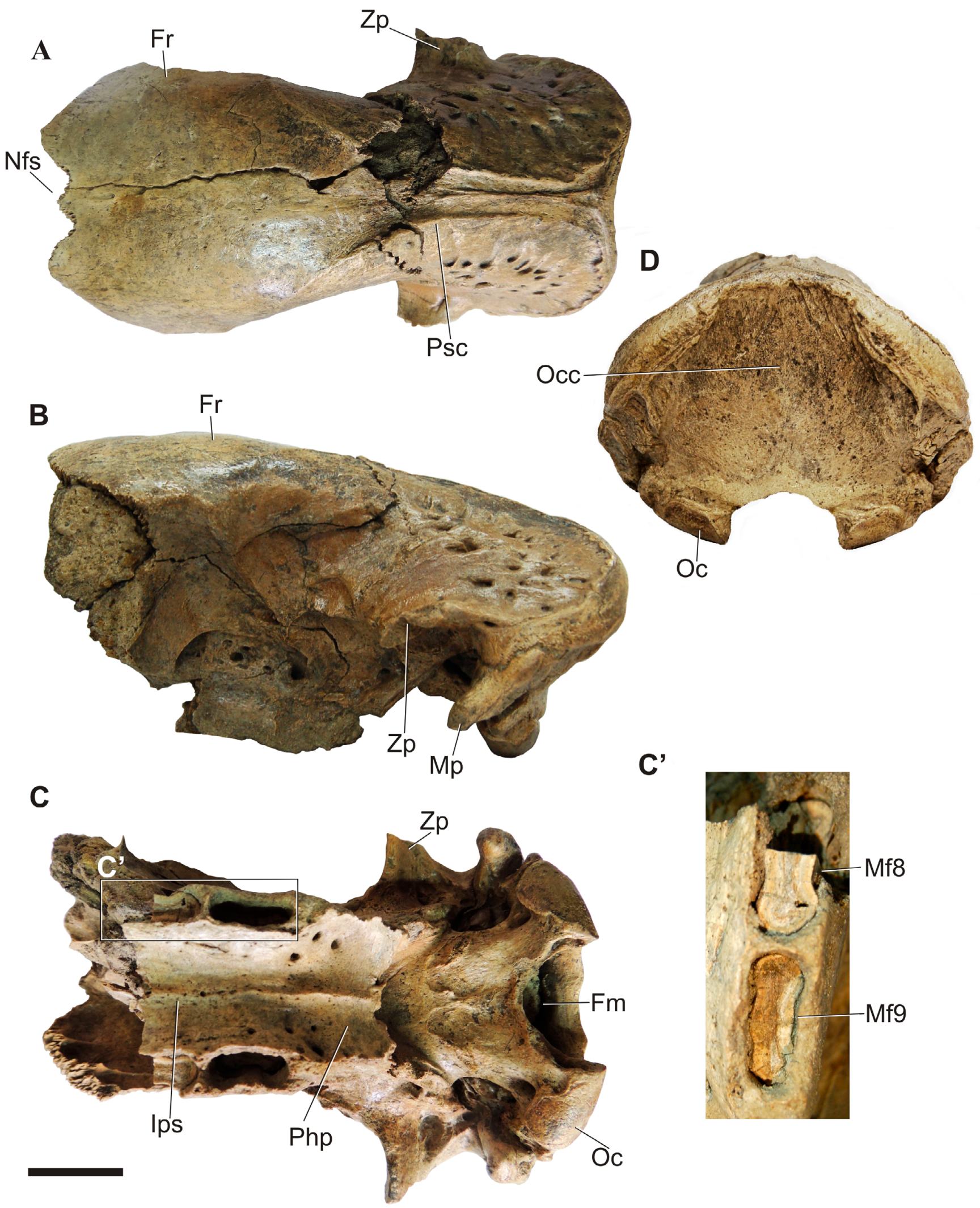

Figure 3. Pampatherium humboldtii (MCTFM-PV 0861), skull in dorsal (A), left lateral (B), ventral (C) and occipital (D) views. C', molariform teeth Mf8 and Mf9 in occlusal view. Abbreviations: Fm, foramen magnum; Fr, frontal; Ips, interpalatine suture; Mf8, eighth upper molariform; Mf9, ninth upper molariform. Mp, mastoid process; Nfs, nasofrontal suture; Occ, occipital central concavity; Oc, occipital condyle; Php, palatine horizontal process; Psc, parasagittal crest; $\mathbf{Z p}$, zygomatic process. Scale bar $=30 \mathrm{~mm}$. 
the interparietal suture, is short and is separated from the parasagittal crests by a distance of about $7.0 \mathrm{~mm}$ in the middle region. Each parasagittal crest (Psc) forms a continuous and curved line, diverging from one another from the middle region of the parietal to the post-orbital process of the frontal, denominated in this region as the external frontal crest. The post-orbital processes of the frontals are short and rounded.

Lateral view (Figure 3B): The observations were based on the left side due to the better preservation of the structures of this side of the maxilla. In this view, it is possible to observe that the lacrimal, zygomatic arch, anterior portion of the maxilla, nasal and premaxilla were not preserved. The frontal is markedly convex laterolaterally and anteroposteriorly. The boundaries between the maxilla, orbitosphenoid and alisphenoid bones are not visible. The height of the mandibular fossa to the interparietal suture is $51.63 \mathrm{~mm}$ and of the palate, at the level of the posterior border of the last molariform, to the interfrontal suture is $115.81 \mathrm{~mm}$. The mastoid process $(\mathrm{Mp})$, anteroventrally oriented, is rectilinear and $42.55 \mathrm{~mm}$ long. The cranial foramina identified in this view are: the proximal opening of the infraorbital canal; the optic foramen, for the passage of the nerve of the same name (n. II); the sphenoid fissure (sphenoorbital fissure) for the passage of the oculomotor (n. III), pathetic (n. IV), the ramus ophthalmic (n.V1) and maxillary (n. V2) of the trigeminal (n. V) and the abducent (n.VI) nerves; the spheno-palatine foramen, for the smaller palatine vessels; the oval foramen for the mandibular ramus (V3) of the trigeminal; and the foramen of the transverse canal. It is important to highlight that the foramen of the transverse canal was not identified in the right side of the specimen. The presence of vascular foramina in the maxillary region between the maxillary foramen and the other foramina is also observed.

Ventral view (Figure 3C): Palatal portion - The premaxillae, pterygoids, tympanic rings and the palatine and maxillae anterior portions up to the seventh molariform are absent. The interpalatine suture (Ips) is poorly visible. The width of the palatine, at the level of the posterior limits of the last molariforms, is $33.39 \mathrm{~mm}$. The horizontal process of the palatine (Php) is concave and presents accessory palatine foramina. Cranial portion - The basis of the zygomatic process $(\mathrm{Zp})$ of the squamous portion of the temporal bone is vertically oriented. The mandibular fossa is deep and the retroglenoid foramen is located within it. The basioccipital presents an anteroposterior length of $30.59 \mathrm{~mm}$ and width of $49.97 \mathrm{~mm}$. In addition, the most posterior region of the basioccipital, close to the foramen magnum $(\mathrm{Fm})$, presents a non-accentuated concavity. The absence of the tympanic rings, together with the endo- and ectotympanics, makes it impossible to accurately visualize the stylomastoid foramina and the jugular foramina. The absence of the tympanic rings also allowed the observation of the petrous part of the temporal, which is found totally preserved, with the promontories and oval and round fenestrae present. It is noticed that none of the specimens of pampatheres described in the literature present the tympanic rings. The anterior condylar foramina, responsible for the passage of the hypoglossal nerve (n. XII), are positioned very close to the occipital condyles (Oc), and bifurcate internally. The foramen magnum is suboval and facing ventrally. Its transverse diameter measures $34.0 \mathrm{~mm}$ and the anteroposterior diameter is $24.5 \mathrm{~mm}$. The occipital condyles are parallelogram shaped, the width of the condyle being $26.6 \mathrm{~mm}$ on the right side and $29.63 \mathrm{~mm}$ on the left side. Therefore, the foramen magnum is wider than the width of each of the condyles. The bicondylar distance, from the extremity of one occipital condyle to the other, is $90.0 \mathrm{~mm}$. The medial fossae to the occipital condyles are also visible, measuring about $7.97 \mathrm{~mm}$ in diameter. The clefts that separate the occipital condyles from the long and rectilinear mastoid processes present $5.0 \mathrm{~mm}$ of spacing on each side of the skull.

Occipital view (Figure 3D): The occipital bone presents as short and wide, with a height of $68.1 \mathrm{~mm}$ and width of $117.18 \mathrm{~mm}$. A significant concavity is prominent in the central region of the occipital (Occ), between the prominent nuchaldorsal crests on each side of the skull. The nuchal-dorsal is formed by the parieto-occipital suture and is $20.0 \mathrm{~mm}$ thick in its most prominent portion, with a slight roughness. The specimen does not have an occipital crest (medial crest in the occipital). The paraoccipital processes are positioned laterally to the occipital condyles and are reduced. The oblique grooves extending from the clefts present well-preserved supramastoid foramina. In this region of confluence, between the petrosal and the occipital on each side, the height at the level of the upper border of the foramen magnum is $17.9 \mathrm{~mm}$.

Dentition (Figure 3C'): The left and right eighth upper molariforms (Mf8) and the left ninth upper molariform (Mf9) are preserved as fragments inside their respective alveoli. The teeth present two lingual grooves and two buccal grooves, which give them a trilobate aspect. The mesiodistal length of the Mf8 is $23.28 \mathrm{~mm}$ and the linguolabial width at the intermediate lobe level is approximately $7.5 \mathrm{~mm}$. Mf9 has a mesiodistal length of $19.5 \mathrm{~mm}$ and a linguolabial width of 6.65 $\mathrm{mm}$ (Table 3). It is noted that the molariforms are elongated mesiodistally and narrow linguolabially, and that the Mf8 is longer and less narrow than the Mf9. The alveolar septum thickness (interdental space) is $2.0 \mathrm{~mm}$ between Mf8 and Mf9. The lingual alveolar borders are parallel to each other.

Table 3. Dental measurements (in $\mathrm{mm}$ ) of the eighth and ninth molariforms of pampathere specimens. *At the level of the intermediate lobe.

\begin{tabular}{cccc}
\hline Dentary specimen & Molariform & $\begin{array}{c}\text { Mesiodistal } \\
\text { length }\end{array}$ & $\begin{array}{c}\text { Linguolabial } \\
\text { width }\end{array}$ \\
\hline \multirow{2}{*}{ MCTFM-PV 0861 } & Mf8 & 23.28 & $7.50^{*}$ \\
& Mf9 & 19.50 & $6.65^{*}$ \\
\hline \multirow{2}{*}{ MHD-P-28 } & Mf8 & 21.70 & $8.80^{*}$ \\
& Mf9 & 20.0 & $8.60^{*}$ \\
\hline \multirow{2}{*}{ ZMK 1/1845:2314/2318 } & Mf8 & 18.05 & $7.70^{*}$ \\
& Mf9 & 19.25 & $7.0^{*}$ \\
\hline \multirow{2}{*}{ MACN PV 11543 } & Mf8 & 15.40 & - \\
& Mf9 & 17.90 & - \\
\hline \multirow{2}{*}{ MCL-501/01 } & Mf8 & 23.28 & 7.39 \\
& Mf9 & 16.24 & 9.65 \\
\hline \multirow{2}{*}{ MERO-P-02 } & Mf8 & 21.0 & - \\
\hline
\end{tabular}


Comparative analysis. Dorsal view: The "W" shape of the nasofrontal suture and the internasal apophysis of the frontal of the specimen from Rio Grande do Sul here described (MCTFM-PV 0861) is different from the Pleistocene pampathere from the State of Rondônia, Holmesina rondoniensis (MERO-P-002, holotype), which takes the shape of an inverted "V". On the other hand, it resembles the specimens of Pampatherium humboldtii (MHD-P-28 from the Pleistocene of Uruguay; ZMK 1/1845:2314 and ZMK 1/1845:2318 from Lagoa Santa region, Minas Gerais). The anteroposterior length of the frontals of MCTFM-PV 0861 $(110.0 \mathrm{~mm}$ ) is closer to that of P. humboldtii (MHD-P-28, $113.7 \mathrm{~mm}$ ) and P. typum (MACN PV 11543, $111.0 \mathrm{~mm}$ ) from the Pleistocene of Argentina, and differs from $H$. rondoniensis (MERO-P-02, $97.0 \mathrm{~mm}$ ). The anteroposterior length of the parietals of MCTFM-PV $0861(80.0 \mathrm{~mm})$, including the lambdoidal crest portion, is shorter than what is observed in H. paulacoutoi (MCL-501/01, holotype, $94.42 \mathrm{~mm}$ ) from the Pleistocene of the State of Bahia, and in P. humboldtii (ZMK 1/1845:2314/2318, $\sim 92.0 \mathrm{~mm}$ ). According to Ubilla (1996), the anteroposterior length of the parietal of the specimen of P. humboldtii (MHD-P-28) is $72.0 \mathrm{~mm}$; however, the author does not specify if the lambdoidal crest was included in the measurement. The lambdoidal crest of MCTFM-PV $0861(15.87 \mathrm{~mm})$ has more similarities with P. typum (MACN PV 11543) and P. humboldtii (ZMK 1/1845:2314/2318, $12.9 \mathrm{~mm}$ ), with the lambdoidal crests being slightly wrinkled and shorter than in the crest of $H$. paulacoutoi (MCL-501/01), which is more wrinkled and longer $(28.17 \mathrm{~mm})$. The parietals of MCTFM-PV 0861 present more than 15 vascular foramina for each parietal bone, as in P. humboldtii (MHD-P-28 and ZMK 1/1845:2314) and P. typum (MACN PV 11543). This feature differs from $H$. paulacoutoi (MCL-501/01) and $H$. rondoniensis (MERO-P-02), which present on average seven to eight foramina per parietal. The width of the skull MCTFM-PV 0861 at the level of the postorbital constriction $(71.29 \mathrm{~mm})$ is relatively wider than that of H. paulacoutoi (MCL-501/01, $67.68 \mathrm{~mm}$ ) and thinner than that of $P$. humboldtii (ZMK 1/1845:2314/2318, 81.30 $\mathrm{mm})$. In addition, the width of the skull in MCTFM-PV 0861, at the level of mandibular fossae $(110.52 \mathrm{~mm})$, even though different, is approximate to that of $H$. paulacoutoi (MCL-501/01, $112.0 \mathrm{~mm}$ ) and P. humboldtii (ZMK $1 / 1845: 2314 / 2318,107.95 \mathrm{~mm})$. The parasagittal crests (= external frontal crest, at the level of the frontals) in MCTFM-PV 0861 are similarly arranged as in P. humboldtii (MHD-P-28). In the specimen MCTFM-PV 0861, the divergence between the parasagittal crests occurs from the midline of the parietals and not at the level of the frontoparietal suture, as in the case of P. typum (MACN $\mathrm{PV} 11543$ ) and $H$. rondoniensis (MERO-P-002). The space between the parasagittal crests and the sagittal crest is smaller in P. humboldtii (ZMK 1/1845: 2314/2318, about $3.5 \mathrm{~mm}$ ) and in H. paulacoutoi (MCL-501/01, about $2.6 \mathrm{~mm}$ ) when compared to that of MCTFM-PV 0861. The sagittal crest in MCTFM-PV 0861 is lower than in all compared specimens, more resembling $P$. humboldtii (MHD-P-28).

Lateral view: The frontals of the specimen MCTFMPV 0861 have a convexity similar to that of Pampatherium humboldtii (MHD-P-28 and ZMK 1/1845:2314/2318) and $P$. typum (MACN PV 11543), whereas in H. paulacoutoi (MCL501/01) and H. rondoniensis (MERO-P-002) the frontals are less convex and a little flattened. The mastoid process of MCTFM-PV presents similarities with the specimens of $P$. humboldtii (MHD-P-28 and ZMK 1/1845:2314/2318) and P. typum (MACN PV 11543) because it is rectilinear and it does not contain a midline curvature in its ventral portion, in contrast to what is observed in H. paulacoutoi (MCL-501/01) and H. rondoniensis (MERO-P-002). The length of the mastoid process of MCTFM-PV $0861(42.55 \mathrm{~mm})$ resembles that of $P$. humboldtii (ZMK 1/1845:2314/2318, $44.3 \mathrm{~mm}$ ) and is longer than in H. paulacoutoi (MCL-501/01, $38.32 \mathrm{~mm}$ ). The height of the skull, at the limit between the mandibular fossa and the interparietal suture, in MCTFM-PV $0861(51.63 \mathrm{~mm})$ is lower than in H. paulacoutoi (MCL-501/01, $64.38 \mathrm{~mm}$ ). The height of the palate, from the level of the posterior edge of the Mf9 to the interfrontal suture, is greater in MCTFM-PV 0861 (115.81 $\mathrm{mm}$ ) than in H. paulacoutoi (MCL-501/01, $101.99 \mathrm{~mm}$ ). The configuration of the cranial foramina of MCTFM-PV 0861 resembles that verified for $P$. humboldtii (MHD-P-28) through a digital reconstruction of its endocranial cast (Tambusso $\&$ Fariña, 2015). The configuration of the cranial foramina of the H. paulacoutoi (MCL-501/01) is characterized as presenting an unindividualized optic foramen and the absence of a transverse canal foramen (Cartelle \& Bohórquez, 1985), which is different to what is observed in the specimen here described (MCTFM-PV 0861), which contains an individualized optic foramen and the transverse canal foramen only on the left side of the skull. The fact that the transverse canal foramen is not on the right side of the skull suggests that it could be in confluence with the oval foramen or even absent, which could indicate that this character is variable and should be dealt with caution among pampatheres.

Ventral view: The interpalatine suture of the skull described (MCTFM-PV 0861) is elevated as in Pampatherium humboldtii (MHD-P-28 and ZMK 1/1845:2314/2318) and Holmesina rondoniensis (MERO-P-002), which differs from P. typum (MACN PV 11543) and H. paulacoutoi (MCL501/01), which present a flattened palatine region, without transversal concavities or elevation of the interpalatine suture. The width of the palatine at the level of the posterior edge of Mf9 in MCTFM-PV $0861(33.39 \mathrm{~mm})$ is more approximated to that of P. humboldtii (MHD-P-28, 27.6 $\mathrm{mm}$; ZMK 1/1845:2314, $30.3 \mathrm{~mm}$ ) and $H$. rondoniensis (MERO-P-002, $27.0 \mathrm{~mm}$ ) than to H. paulacoutoi (MCL$501 / 01,41.39 \mathrm{~mm}$ ). The concavity observed on the horizontal process of the palatine in MCTFM-PV 0861 is similar to that of P. humboldtii (MHD-P-28 and ZMK 1/1845:2314/2318) and P. typum (MACN PV 11543), but different from the specimens of $H$. rondoniensis (MERO-P-002) and $H$. paulacoutoi (MCL-501/01), which present a flattened shape to the horizontal process of the palatine. The width 
of the basioccipital of MCTFM-PV $0861(49.97 \mathrm{~mm})$ is bigger than that of $P$. humboldtii (ZMK 1/1845:2314, 38.6 $\mathrm{mm}$ ) and $H$. paulacoutoi (MCL-5-1/01; $43.14 \mathrm{~mm}$ ). $H$. rondoniensis (MERO-P-002) has a wider basioccipital than H. paulacoutoi (MCL-501/01), according to Góis et al. (2012). The length of the basioccipital is shorter in MCTFMPV 0861 (30.39 mm) than in H. paulacoutoi (MCL-501/01; $38.64 \mathrm{~mm}$ ). Furthermore, MCTFM-PV 0861 differs from $H$. paulacoutoi (MCL-501/01) by the absence of a concavity on the posterior basioccipital portion, which is similar to P. humboldtii (ZMK 1/1845:2314/2318). The vertically oriented base of the zygomatic process of the squamous portion of the temporal bone in MCTFM-PV 0861 is similar in shape to that of P. humboldtii (MHD-P-28 and ZMK 1/1845:2314/2318) and different to that of $H$. paulacoutoi (MCL-501/01), whose structure is projected laterally and horizontally. The mandibular fossa where the retroglenoid foramen is situated is deeper in MCTFM-PV 0861 than in $H$. paulacoutoi (MCL-501/01). The positioning of the anterior condyloid foramen near to the occipital condyle in MCTFMPV 0861 resembles that of $P$. humboldtii (MHD-P-28 and ZMK 1/1845:2314/2318) and P. typum (MACN PV 11543) and differs from that of $H$. paulacoutoi (MCL-501/01). The internal bifurcation of the condyloid foramen does not occur in specimens of $P$. humboldtii (ZMK 1/1845:2314/2318) and H. paulacoutoi (MCL-501/01). The diameters of the medial fossae of the occipital condyles in MCTFM-PV 0861 (7.97 $\mathrm{mm}$ ) are relatively smaller compared to $H$. paulacouto $i$ (MCL-501/01, $10.63 \mathrm{~mm}$ ). The suboval and more ventralized shape of the foramen magnum in MCTFM-PV 0861 is more similar to that of P. humboldtii (MHD-P-28) and P. typum (MACN PV 11543), but is different from the circular and posteriorly directed foramen magnum of $H$. paulacouto $i$ (MCL-501/01). The transversal diameter of the foramen magnum in MCTFM-PV $0861(34.0 \mathrm{~mm})$ is the same as in P. humboldtii (MHD-P- 28, $34.0 \mathrm{~mm}$ ), is slightly smaller than in H. rondoniensis (MERO-P-002, $39.0 \mathrm{~mm}$ ) and is slightly bigger than in $H$. paulacoutoi (MCL-5-1/01, $32.0 \mathrm{~mm}$ ), but the anteroposterior diameter of MCTFMPV $0861(24.5 \mathrm{~mm})$ is similar to that of $H$. paulacoutoi (MCL-501/01, $24.5 \mathrm{~mm}$ ). The parallelogram shape of the occipital condyles in MCTFM-PV 0861 is the same as in $P$. humboldtii (MHD-P-28 and ZMK 1/1845:2314/2318), $H$. rondoniensis (MERO-P-002) and H. paulacoutoi (MCL$501 / 01$ ) and different from the relatively quadrangular shape of P. typum (MACN PV 11543). The average width of the occipital condyles of MCTFM-PV $0861(26.6 \mathrm{~mm})$ resembles that of P. humboldtii (MDH-P-28, $24.40 \mathrm{~mm}$ ) and $H$. rondoniensis (MERO-P-002, $29.0 \mathrm{~mm}$ ), being smaller than $H$. paulacoutoi (MCL-501/01, 31.0 mm) and the specimen ZMK 1/1845:2314/2318 of $P$. humboldtii (32.9 mm). In contrast to MCTFM-PV 0861, the transversal measurements of each occipital condyle and of the foramen magnum of $H$. paulacoutoi (MCL-501/01) are equivalent. The bicondylar distance in MCTFM-PV $0861(90.0 \mathrm{~mm})$ is similar to $H$. paulacoutoi (MCL-501/01, $91.0 \mathrm{~mm}$ ) and a bit bigger than $P$. humboldtii (MHD-P-28, $83.5 \mathrm{~mm}$ ) and
H. rondoniensis (MERO-P-002, $88.0 \mathrm{~mm}$ ). The clefts that separate the occipital condyles from the mastoid processes in MCTFM-PV $0861(5.0 \mathrm{~mm})$ are narrower than in $H$. paulacoutoi (MCL-501/01).

Occipital view: The occipital bone in MCTFM-PV 0861 is a bit lower and wider $(68.1 \mathrm{~mm} \times 117.18 \mathrm{~mm})$ than in Holmesina paulacoutoi $(71.88 \mathrm{~mm} \times 111.98 \mathrm{~mm})$ and $H$. rondoniensis (MERO-P-002), and less wide than in Pampatherium humboldtii (ZMK 1/1845:2314/2318, $125.6 \mathrm{~mm}$ ). MCTFMPV 0861 presents a central concavity at the occipital, as in P. humboldtii (MHD-P-28 and ZMK 1/1845:2314/2318), which is different to what occurs in H. paulacoutoi (MCL501/01) and H. rondoniensis (MERO-P-002), whose central region of the occipital is flattened. The specimen under study (MCTFM-PV 0861) does not present an occipital crest, while in P. humboldtii (ZMK 1/1845:2314/2318) this structure is vestigial, differing from $H$. paulacoutoi (MCL-501/01), which presents evidence of a central occipital crest. The thickness of the nuchal-dorsal crest in MCTFM-PV $0861(20.0 \mathrm{~mm})$ is larger than in $H$. paulacoutoi $(13.0 \mathrm{~mm})$ and differs from it by being rough and posteriorly projected, as occurs in $P$. typum (MACN PV 11543) and P. humboldtii (MHD-P-28 and ZMK 1/1845:2314/2318). The height at the level of the upper edge of the foramen magnum to the supramastoid foramen in MCTFM-PV $0861(17.9 \mathrm{~mm})$ is shorter than in H. paulacoutoi (MCL-501/01, 20.0 mm). The paraoccipital process is reduced like in all other comparative pampatheres.

Dentition: The specimen MCTFM-PV 0861 has trilobate molariforms Mf8 and Mf9 as in Pampatherium humboldtii (MHD-P-28), differing from Holmesina paulacoutoi (MCL501/01) and H. rondoniensis (MERO-P-02), whose teeth are bilobate. Apparently, the Mf8 and Mf9 of MCTFM-PV 0861 seem to differ from the specimen ZMK 1/1845:2314/2318 of P. humboldtii, because the latter has a peculiar morphology, with two lingual and one buccal groove. The mesiodistal diameter of Mf8 of MCTFM-PV 0861 $(23.28 \mathrm{~mm})$ is similar to the alveolus of $H$. paulacoutoi (MCL-501/01, $23.28 \mathrm{~mm}$ ), and is bigger than teeth of $H$. rondoniensis (MERO-P-002, $21.0 \mathrm{~mm}$ ), P. typum (MACN PV 11543, $15.4 \mathrm{~mm}$ ) and $P$. humboldtii (MHD-P-28, 21.7 mm; ZMK 1/1845: 2314/2318, $18.05 \mathrm{~mm}$ ). The linguolabial diameter of Mf8 of MCTFM-PV $0861(7.5 \mathrm{~mm})$ is similar to the alveolus of $H$. paulacouto (MCL-501/01, $7.39 \mathrm{~mm}$ ) and smaller than the teeth of $P$. humboldtii (MHD-P-28, 8.8 mm; ZMK 1/1845:2314/2318, $7.7 \mathrm{~mm}$ ). The mesiodistal diameter of Mf9 of MCTFM-PV $0861(19.5 \mathrm{~mm})$ is longer than in $H$. paulacoutoi (MCL501/01, $16.24 \mathrm{~mm}$ ), H. rondoniensis (MERO-P-02, 17.1 $\mathrm{mm}$ ) and P. typum (MACN PV 11543, $17.9 \mathrm{~mm}$ ), and is similar to that of $P$. humboldtii (MHD-P-28, $20.0 \mathrm{~mm}$; ZMK 1/1845:2314/2318, alveolus, $19.25 \mathrm{~mm}$ ). In contrast, the linguolabial diameter in MCTFM-PV $0861(6.65 \mathrm{~mm})$ is shorter than in $H$. paulacoutoi (MCL-501/01, $9.65 \mathrm{~mm}$ ) and P. humboldtii (MHD-P-28, $8.6 \mathrm{~mm}$ ), but is similar to the alveolus of the specimen ZMK 1/1845:2314/2318 (7.0 $\mathrm{mm}$ ) of $P$. humboldtii (Table 3).

\section{DISCUSSION}




\section{Morphological and taxonomic remarks about the mate- rial from Rio Grande do Sul}

The cranial specimen presented in this study (MCTFM-PV 0861) is attributed to the species Pampatherium humboldtii. Features observed in specimens of Holmesina paulacoutoi (MCL 501/01) and H. rondoniensis (MERO-P-002) that differ from $P$. humboldtii are, mainly: bilobate, short and wide Mf8 and Mf9; base of the zygomatic process of the squamous portion of the temporal horizontally oriented; short mastoid process with a medial curvature on its ventral extremity; and the absence of a central concavity of the occipital between both nuchal-dorsal crests. Features that distinguish P. typum (MACN PV 11543) from the studied P. humboldtii specimen (MCTFM-PV 0861) are, mainly: arrangement of parasagittal crests; the quadrangular shape of the occipital condyles; and dental morphology, in which Mf8 is smaller than Mf9, whereas in the Rio Grande do Sul specimen Mf8 is larger than Mf9 (Table 3).

In other respects, the specimen from Rio Grande do Sul (MCTFM-PV 0861) is closer to the specimens of Pampatherium humboldtii (MHD-P-28 and ZMK 1/1845:2314/2318), particularly to MHD-P-28, from Uruguay. Among the characters that define them as similar, the following stand out: length and convexity of the frontals; "W" shape of the nasofrontal suture with the internasal apophysis of the frontal; arrangement of the parasagittal crests; short sagittal crest; long and rectilinear mastoid process; configuration of the cranial foramina; interpalatine suture elevated; base of the zygomatic process of the squamous portion of the temporal vertically oriented; concavity in the horizontal process of the palatine; foramen magnum with the same transversal diameter and suboval shape; occipital condyles with parallelogram shape; presence of a central concavity in the occipital; wide occipital; and trilobate, long and narrow Mf8 and Mf9 (Figure 3).

\section{Taxonomic remarks on Pampatherium humboldtii}

The pampathere taxa belonging to the fossil fauna of the Lagoa Santa region (e.g. Lund, 1839a, 1840) were partially figured without, however, the designation of a holotype for the species. In the review of the P.W. Lund Collection made by Winge (1915), neither is a lectotype designated, nor is the scientific collection number mentioned. In the case of the species Pampatherium humboldtii (Lund, 1839a,b), the specimen ZMK 618 (Figure 4) from Lund's manuscript catalog (a left dentary collected in Lapa do Baú) was chosen by Cartelle (1992) to be the lectotype of the species, but in his unpublished Doctoral Thesis. The author further comments and explains that the first material of $P$. humboldtii presented in Lund's manuscript catalog would be number 150, a mandibular fragment, and that the first fossils described and figured would correspond to less significant osteoderms (Lund, 1839a, pl. 1, figs. 7-10, 12-13). In addition, other material referred to $P$. humboldtii is also figured by Lund (1839a, pl. 2, figs. 1-3, pl. 12, figs. 1, 6-7 and pl. 13, figs. 2, 6-11). Edmund (1996) considered the same left dentary figured by Lund (1842, pl. 34, fig. 9) as a lectotype for the species, but cites the specimen as number 150 and as originating from Periperi I, unlike Cartelle (1992). Later, Góis (2013) remarked that both specimens ZMK 150 and ZMK 618 were misplaced. Consulting the P.W. Lund Collection in 2017, it was possible to locate only the specimen number 618 (referred to throughout this work as ZMK 618). Observing this specimen in hand, we noted that it is the same specimen that had been figured in medial view by Lund (1840, pl. 14, fig. 1), in occlusal view by Lund (1842, pl. 34, fig. 9) and in lateral view by Winge (1915, pl. 10). In addition, it is possible to observe, in the view presented by Winge (1915, pl. 10), the number 618 written on the specimen. Regarding the specimen number ZMK 150, listed as the first specimen of the species $P$. humboldtii in Lund's manuscript catalog (Cartelle, 1992), we have noticed that it was mentioned by Edmund (1996) as referring to the specimen ZMK 618 (left dentary). Thereby, we checked the P.W. Lund Collection and the specimen ZMK 150 is a right mandibular fragment, just as Cartelle (1992) had referenced. We here suggest that this is the right mandibular fragment figured in Lund (1939a, pl. 2, figs. 1-3). Considering that both Cartelle (1992) and Edmund (1996) have agreed that the lectotype should be the left dentary, that the same has been figured by Lund (1840, pl. 14, fig. 1, 1842, pl. 34, fig. 9), and that, on the specimen, there is marked the number 618 , we agree with these authors and suggest ZMK 618 to be considered the lectotype of the species Pampatherium humboldtii.

Another relevant question about the taxonomic nomenclature described, based on the pampathere material found and published by Lund (1839, 1840, 1842), has emerged, regarding the skull which was referred to by Góis (2013) as "UZM 2314" (= ZMK 1/1845:2314; Figure 5). This skull was the subject of different publications and has received several distinct taxonomic names: Chlamydotherium (= Pampatherium) humboldtii by Lund (1839a); Chlamydotherium majus by Winge (1915, pl. 10); and, more recently, Holmesina major by Góis (2013, pl. 39) and Góis et al. (2012). As previously mentioned, in proposing the species C. humboldtii, Lund (1839a) described the cranial material (see Paula Couto, 1950, p. 137-138) without figuring or mentioning its catalog number, which is probably the reason why subsequent mistakes occurred. However, Lund (1843) mentioned that, in Lapa do Baú, only fossils of the species C. humboldtii were recovered. Therefore, we consider that the explanation for this question resides, mainly, in Winge's publication (1915). In reviewing the Brazilian fossils collected and studied by Lund (1839a,b, 1840, 1842, 1843), this author presented a list of pampatheres found in each cave, illustrating a fragmented skull (Winge, 1915, pl. 10) and explaining its origin as being Lapa do Baú. We have noted in the P.W. Lund Collection that the skull figured by Winge (1915), due to the fact that it is fragmented and is divided into two parts, received two different collection numbers (ZMK 1/1845:2314 and ZMK 1/1845:2318). Although it was considered as C. majus by Winge (1915), it is clear that the cranial material identified as ZMK 1/1845:2314 and ZMK 1/1845:2318 represents one of the first specimens reported in Lund's "Second Memoir 


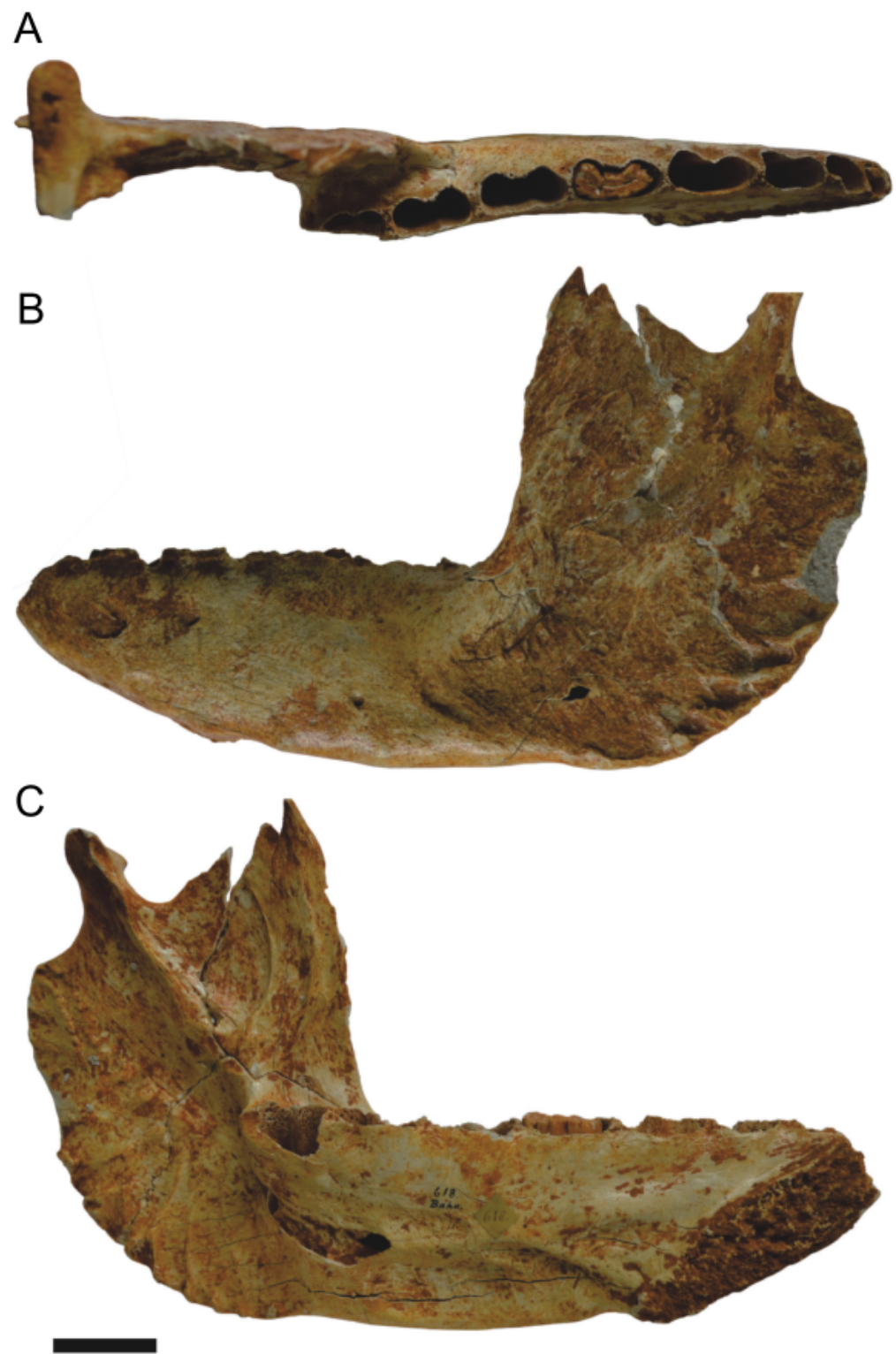

Figure 4. Lectotype of Pampatherium humboldtii (ZMK 618), left dentary in occlusal (A), labial (B) and lingual (C) views. Scale bar $=30 \mathrm{~mm}$.

of Cave Fauna" (1839a) as C. humboldtii (= Pampatherium humboldtii). Therefore, the present study argues, based on the faunal lists of fossiliferous localities reported, and the descriptions made by Lund (1839a, 1843), that the skull described as $C$. humboldtii by Lund (1839a) is the same as that which was later illustrated by Winge (1915), referred to by Góis et al. (2012) and figured by Góis (2013) as Holmesina major. We have also checked that, along with the specimens ZMK 1/1845:2314 and ZMK 1/1845:2318, there are two labels, one handwritten and the other typed. The former is older and contains both $C$. humboldtii and $C$. majus, which suggests that, at some point, this material has been attributed to the first species. The specimens ZMK 1/1845:2314/2318 present features more similar to the skulls attributed to the genus Pampatherium than to the genus Holmesina. The anteroposterior length of the parietals at the midline of the specimens ZMK 1/1845:2314 and ZMK 1/1845:2318 is similar to that of Holmesina paulacoutoi (MCL-501/01); on the other hand, the characters: length and convexity of the frontals; "W" shape of the nasofrontal suture with the frontal internasal apophysis; long and rectilinear mastoid process without medial curvature in the ventral portion; vertically oriented base of the zygomatic process of the squamous portion of the temporal; concavity in the palatine horizontal process; parallelogram shape of the occipital condyles; presence of a central concavity in the occipital; large occipital; and long and narrow molariforms represent the species Pampatherium humboldtii. Thus, in this study we consider that the specimens ZMK 1/1845:2314 and ZMK 1/1845:2318 correspond to one single fragmented skull, which is the first representative cranial material described for the species Pampatherium humboldtii (as referred in Table 2), and MCTFM-PV 0861 from the South of Brazil is described here as the same species. 

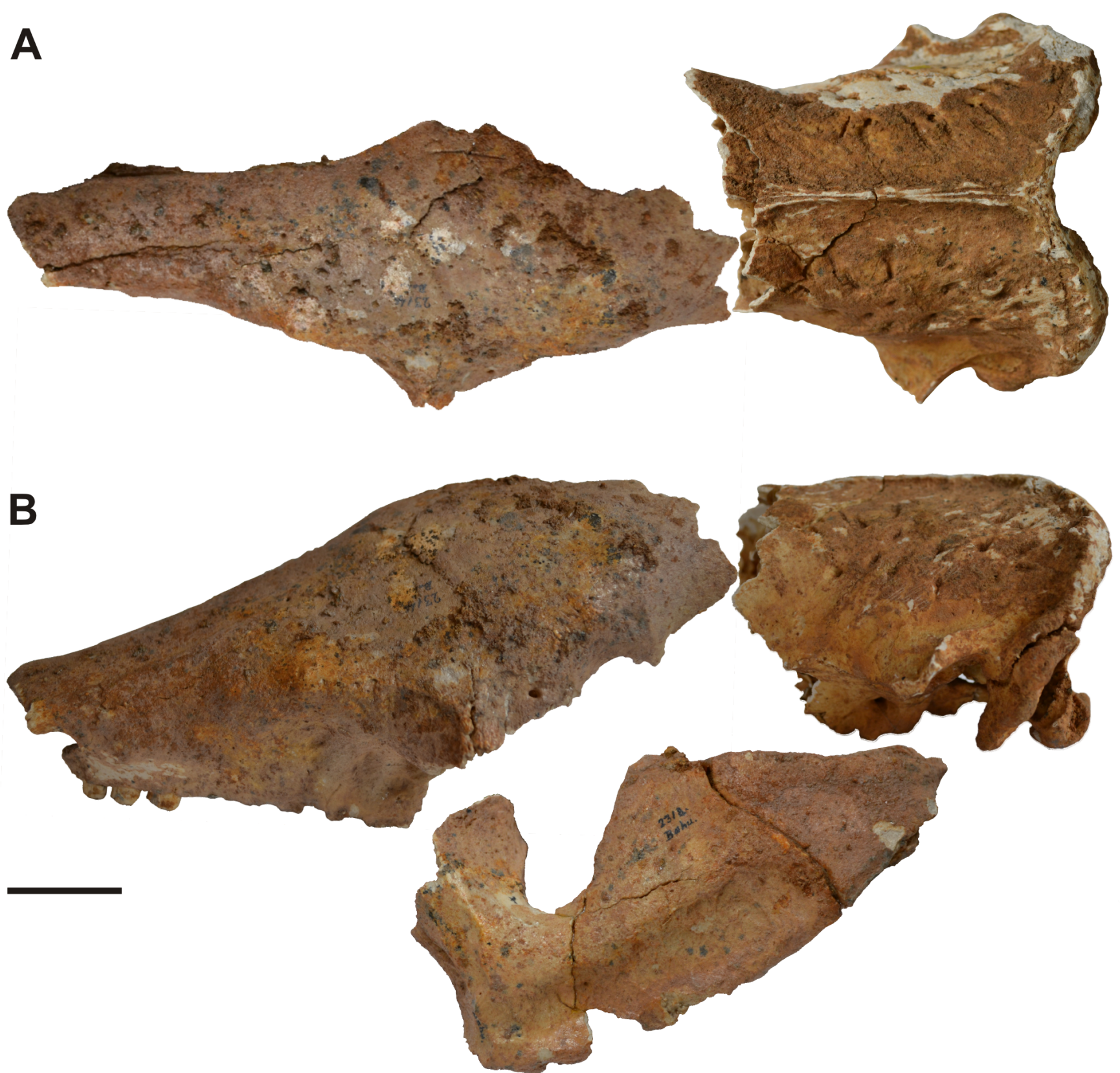

Figure 5. Part of the fragmented skull of Pampatherium humboldtii (ZMK 1/1845:2314 and ZMK 1/1845:2318). Scale bar $=30 \mathrm{~mm}$.

\section{CONCLUSION}

The description of the specimen MCTFM-PV 0861 and its comparison with Pleistocene pampatheres from Argentina, Brazil and Uruguay are the basis for its attribution to the species Pampatherium humboldtii. Because the Pampatheriidae fossil record of the State of Rio Grande do Sul consisted mainly of osteoderms, the information presented here about the skull MCTFM-PV 0861 is relevant to the anatomical study of the pampatheres.

Together with this study of the material from Rio Grande do Sul, we have reviewed in a preliminary way the Pampatheriidae material from the P.W. Lund Collection. The left dentary ZMK 618 was found and we suggest here that it represents the lectotype of the species Pampatherium humboldtii, as previously suggested. The specimens ZMK 1/1845:2314 and ZMK 1/1845:2318 present a morphology more approximated to Pampatherium humboldtii than to P. typum and Holmesina specimens, and this seems to be corroborated by their collection site (Lapa do Baú).

\section{ACKNOWLEDGMENTS}

We thank C. Cartelle and L. Vilaboim, from Museu de Ciências Naturais da Pontifícia Universidade Católica de Minas Gerais, Minas Gerais, and K. Kjær, K.M. Gregersen and K.L. Hansen, from Zoologisk Museum, Copenhagen, Denmark, for access and assistance during 
the consultation of the collections of their respective institutions; Fundação Zoobotânica do Rio Grande do Sul for the granted infrastructure; L.A. Hartmann and B.R.S. Molina for assistance with the program ArcGis; F. Góis and L. Gonzalez provided valuable comments to improve the manuscript; $\mathrm{CNPq}$ by granting scholarships to the Programa de Pós-Graduação em Geociências da Universidade Federal do Rio Grande do Sul (T.M.P.F. process 131129/2016-3 and E.L.M. process 140577/2014-9) and CAPES for granting a Doutorado Sanduíche scholarship to E.L.M. (process 88881.134568/2016-01) for consultation of the P.W. Lund Collection, Copenhagen, Denmark.

\section{REFERENCES}

Ameghino, F. 1891. Mamíferos y aves fósiles argentinos. Especies nuevas: adiciones y correciones. Revista Argentina de Historia Natural, 1:240-259.

Avilla, L.S.; Freitas, M.L.; Dominato, V.H.; Soibelzon, E.S.; Castro, M.; Góis, F. \& Luna, C. 2013. Os cingulados (Mammalia: Xenarthra) do Quaternário do Sudeste do estado do Tocantins, Norte do Brasil. Porto Alegre, SBP, p. 48-49 (Paleontologia em Destaque 66).

Bergqvist, L.P.; Gomide M.; Cartelle, C. \& Capilla, R. 1997. Faunaslocais de mamíferos pleistocênicos de Itapipoca/Ceará, Taperoá/ Paraíba e Campina Grande/Paraíba. Estudo comparativo, bioestratinômico e paleoambiental. Revista Universidade Guarulhos - Geociências, 2:23-32.

Bombim, M. 1976. Modelo paleoecológico evolutivo para o Neoquaternário da região da Campanha-Oeste do Rio Grande do Sul (Brasil). A Formação Touro Passo, seu conteúdo fossilifero e a pedogênese pós-deposicional. Porto Alegre, Museu de Ciências da PUCRS, 90 p. (Comunicações 15).

Bordas, A.F. 1939. Craniometría y región auditiva de Clamytherium typum Ameghino. Physis, Revista de La Sociedad Argentina de Ciencias Naturales, 14:447-460.

Bronn, H.G. 1838. Abbildungen und Beschreibungen der fur die Geobirgs-Formationen bezeichnendsten Versteinerugen. Lethea Geognostica, 2:545-1350.

Buchmann, F.S.; Lopes, R.P. \& Caron, F. 2009. Icnofósseis (Paleotocas e crotovinas) atribuídos a mamíferos extintos no sudeste e sul do Brasil. Revista Brasileira de Paleontologia, 12:247-256. doi:10.4072/rbp.2009.3.07

Cahn, A.R. 1922. Chlamyrherium septentrionalis, a fossil edentate new to the fauna of Texas. Journal of Mammalogy, 3:22-24.

Cartelle, C. 1992. Edentata e Megamamiferos herbivoros da Toca dos Ossos, Ourolândia, Bahia, Brasil. Universidade Federal de Minas Gerais, Tese de Doutorado, 600 p.

Cartelle, C. \& Bohórquez, G.A. 1985. Pampatherium paulacoutoi, uma nova espécie de tatu gigante da Bahia, Brasil (Edentata, Dasypodidae). Revista Brasileira de Zoologia, 2:229-254. doi:10.1590/S0101-81751983000400003

Castellanos, A. 1957. Nuevos restos de clamiterios y de ciervo y uma nueva espécie de Phohophorus. Ameghiniana, 1:5-14.

Ciancio, M.R.; Vieytes, E.C. \& Carlini, A.A. 2014. When xenarthrans had enamel: insights on the evolution of their hypsodonty and paleontological support for independent evolution in armadillos. Naturwissenschaften, 101:715-725. doi:10.1007/s00114-014-1208-9

De Iuliis, G.; Bargo, M.S. \& Vizcaíno, S.F. 2001. Variation in skull morphology and mastication in the fossil giant armadillos Pampatherium spp. and allied genera (Mammalia: Xenarthra:
Pampatheriidae), with comments on their systematics and distribution. Journal of Vertebrate Paleontology, 20:743-754. doi:10.1671/0272-4634(2000)020[0743:VISMAM]2.0.CO;2

Delaney, P.J.V. 1965. Fisiografia e geologia da superficie da Planicie Costeira do Rio Grande do Sul. Porto Alegre, Escola de Geologia, UFRGS, 105 p. (Publicação Especial 6).

Delsuc, F.; Gibb, G.C.; Kuch, M.; Billet, G.; Hautier, L.; Southon, J.; Rouillard, J-M.; Ferniciola, J.C.; Vizcaíno, S.F.; MacPhee, R.D.E. \& Poinar, H.N. 2016. The phylogenetic affinities of the extinct glyptodonts. Current Biology Magazine, 4:155-156. doi:10.1016/j.cub.2016.01.039

Delsuc, F.; Vizcaíno, S.F. \& Douzery, E.J.P. 2004. Influence of Tertiary paleoenvironmental changes on the diversification of South American mammals: a relaxed molecular clock study within xenarthrans. BMC Evolutionary Biology, 4:11. doi:10.1186/1471-2148-4-11

Edmund, A.G. 1987. Evolution of the genus Holmesina (Pampatheriidae, Mammalia) in Florida, with remarks on taxonomy and distribution. Pearce-Sellards Series, 45:1-18.

Edmund, A.G. 1996. A review of Pleistocene giant armadillos (Mammalia, Xenarthra, Pampatheriidae). In: K.M. Stewart \& K.L. Seymor (eds.) Paleoecology and palaeoenvironments of late Cenozoic mammals, University of Toronto Press, p. 300-321.

Engelmann, F.F. 1985. The phylogeny of the Xenarthra. In: G.G. Montgomery (eds.) The evolution and ecology of armadillos, sloths and vermilinguas, Smithsonian Institution Press, p. 51-64.

Gaudin, T.J. 1999. The morphology of xenarthrous vertebrae (Mammalia, Xenarthra). Fieldiana, 41:1-38.

Gervais, H. \& Ameghino, F. 1880. Los mamíferos fósiles de la América del Sud. Paris-Buenos Aires, Sabih e Igon, 225 p.

Gibb, G.C.; Condamine, F.L.; Kuch, M.; Enk, J.; Moraes-Barros, N.; Superina, M.; Poinar, H.N. \& Delsuc, F. 2015. Shotgun mitogenomics provides a reference phylogenetic framework and timescale for living xenarthrans. Molecular Biology and Evolution, 3:621-642. doi:10.1093/molbev/msv250

Góis, F.L. 2013. Análisis morfológico y afinidades de los Pampatheriidae (Mammalia, Xenarthra).Universidad Nacional de La Plata, Tese de Doutorado, 312 p.

Góis, F.; González Ruiz, L.R.; Scillato-Yané, G.J. \& Soibelzon, E. 2015. A peculiar new Pampatheriidae (Mammalia: Xenarthra: Cingulata) from the Pleistocene of Argentina and comments on Pampatheriidae diversity. PloS ONE, 10:e0128296. doi:10.1371/ journal.pone.0128296

Góis, F.; Scillato-Yané, G.J.; Carlini, A.A. \& Ubilla, M. 2012. Una nueva espécie de Holmesina Simpson (Xenarthra, Cingulata, Pampatheriidae) del Pleistoceno de Rondônia, Sudoeste de la Amazonia, Brasil. Revista Brasileira de Paleontologia, 15:211-227. doi:10.4072/rbp.2012.2.09

Gomide, M. 1989. Mamíferos pleistocênicos de Itapipoca, Ceará, Brasil, depositados no Museu Nacional. Programa de PósGraduação em Zoologia, Universidade Federal do Rio de Janeiro, Dissertação de Mestrado, 172 p.

Guérin, C. \& Faure, M. 2008. La biodiversité mammalienne au Pléistocène supérieur - Holocène ancien dans la Région du Parc National Serra da Capivara (SE du Piauí, Brésil). FUMDHAMentos, 7:79-93.

Guth, C. 1961. La région temporale des Edentés. Haute-Loire, Imprimerie Jeanne d'Arc Le Puy, 207 p.

Hay, O.P. 1902. Bibliography and catalogue of fossil vertebrata of North America. Reston, The United States Geological Survey, 868 p. (Bulletin 179). 
Hay, O.P. 1926. A collection of Pleistocene vertebrates from southwestern Texas. Washington, D.C., The United States National Museum, 18 p. (Proceedings 24).

Hoffstetter, R. 1952. Les mammiferés pleistocenes de la République de l'Equateur. Paris, Societé Géologique de France, 391 p. (Mémoires 66).

Hoffstetter, R. 1953. Sur la présence d'um tatou géaunt Du genre Holmesina dans Le Pléistocéne de l'Équateur (América Du Sud). Compte Rendu dês Séances de La Societé Géologique de France, 6:101-102.

Kerber, L. \& Oliveira, É.V. 2007. Tafonomia de vertebrados fósseis na localidade Ponte Velha, na Formação Touro Passo (Pleistoceno Superior), oeste do Rio Grande do Sul. In: SIMPÓSIO DE BIODIVERSIDADE, 1, 2007. Resumos, Santa Maria, UFSM, p. 42.

Kerber, L. \& Oliveira, E.V. 2008. Fósseis de vertebrados da Formação Touro Passo (Pleistoceno Superior), Rio Grande do Sul, Brasil: atualização dos dados e novas contribuições. Gaea - Journal of Geosciences, 4:49-64. doi:10.4013/gaea.20082.02

Leidy, J. 1889a. Fossil vertebrates from Florida. Proceedings of the Academy of Natural Sciences of Philadelphia, 41:96-97.

Leidy, J. 1889b. Description of vertebrate remains from Peace Creek, Florida. Transactions of the Wagner Free Institute of Science of Philadelphia, 2:19-32.

Lopes, R.P. 2013. Biostratigraphy of the Pleistocene fossiliferous deposits of southern Brazilian coastal area. Journal Mammalian Evolution, 20:69-82. doi:10.1007/s10914-011-9173-y

Lopes, R.P.; Buchmann, F.S.C.; Caron, F. \& Itusarry, M.E.G. 2005. Barrancas fossilíferas do Arroio Chuí, RS - importante megafauna pleistocênica no extremo sul do Brasil. In: M. Winge; C. Schoobbenhaus; M. Berbert-Born; E.T. Queiroz; D.A. Campos; C.R.G. Souza \& A.C.S. Fernandes (eds.) Sitios Geológicos e Paleontológicos do Brasil, 2, CPRM, 10 p.

Lopes, R.P.; Dillenburg, S.R. \& Schultz, C.L. 2016. Cordão Formation: loess deposits in the southern coastal plain of the state of Rio Grande do Sul, Brasil. Anais da Academia Brasileira de Ciências, 88:2143-2166. doi:10.1590/0001-3765201620150738

Lopes, R.P.; Dillenburg, S.R.; Schultz, C.L.; Ferigolo, J.; Ribeiro, A.M.; Pereira, J.C.; Holanda, E.C.; Pitana, V.G. \& Kerber, L. 2014a. The sea-level highstand correlated to marine isotope stage (MIS) 7 in the coastal plain of the state of Rio Grande do Sul, Brazil. Anais da Academia Brasileira de Ciências, 86:1573-1595. doi:10.1590/0001-3765201420130274

Lopes, R.P.; Kinoshita, A.; Baffa, O.; Figueiredo, A.M.G.; Dillenburg, S.R.; Schultz, C.L. \& Pereira, J.C. 2014b. ESR dating of Pleistocene mammals and marine shells from the coastal plain of Rio Grande do Sul state, southern Brazil. Quaternary International, 352:124-134. doi:10.1016/j.quaint.2013.07.020

Lund, P.W. 1839a. Blik paa Brasiliens Dyreverden för Sidste Jordomvaeltning. Anden Afhandling: Pattedyrene. Lagoa Santa, d. 16d. Novbr. 1837. Det Kongelige Danske Videnskabernes Selskabs Naturvidenskabelige og Mathematike Afhandlinger, 8:61-144.

Lund, P.W. 1839b. Coup d'oeil sur les espèces éteintes de Mammifères du Brésil, extrait de quelques mémoires présentés à l'Académie Royale des Sciences de Copenhague. Annales des Sciences Naturelles, 11:214-234.

Lund, P.W. 1840. Iden. Tredie Afhandling: Fortsaettelse af Pattedyrene. Lagoa Santa d. 12te. Septbr. 1838. Ibidem, 8:217-272.

Lund, P.W. 1842. Blik paa Brasiliens Dyreverden för Sidste Jordomvaeltning. Fjerde Afhandling: Fortsaettelse af Pattedyrene.
Lagoa Santa, den 30te. Januar 1841. Ibidem, 9:137-208.

Lund, P.W. 1843. Blik paa Brasiliens Dyreverden för Sidste Jordomvaeltning. Femte Afhandling: Fortsaettelse af Pattedyrene. Om de nulevende og uddöde. Arter af Rovdyrenes Familie. Lagoa Santa, d. 4de October 1841. Ibidem, 11:1-82.

McKenna, M.C. \& Bell, S.K. 1997. Classification of Mammals. Above the species level. New York, Columbia University Press, $640 \mathrm{p}$.

Oersted, H.C. 1839. Oversigt over det Kongelike Danske Videnskabernes Selskabs Forhandlinger og dets Medlemmers Arbeiter $i$ Aaret 1838. Copenhagen, p. 5-14.

Oliveira, E.V. 1996. Mamíferos Xenarthra (Edentata) do Quaternário do Estado do Rio Grande do Sul. Ameghiniana, 33:65-75.

Oliveira, E.V. 1999. Quaternary vertebrates and climates of Southern Brazil. In: J. Rabassa \& M. Saleme (eds.) Quaternary of South America and Antarctic Peninsula, A.A. Balkema, p. 61-73.

Oliveira, E.V. \& Pereira, J.C. 2009. Intertropical cingulates (Mammalia, Xenarthra) from Quaternary of Southern Brazil: systematics and paleobiogeographical aspects. Revista Brasileira de Paleontologia, 12:167-178. doi:10.4070/rbp.2009.3.01

Oliveira, E.V.; Prevosti, F.J. \& Pereira, J.C. 2005. Protocyon troglodytes (Lund) (Mammalia, Carnivora) in the Late Pleistocene of Rio Grande do Sul and their paleoecological significance. Revista Brasileira de Paleontologia, 8:215-220.

Oliveira, L.D.D. \& Santos, M.F.C.F. 1990. Uma provável ocorrência de Holmesina paulacoutoi Cartelle \& Bohórquez, 1985) nos tanques fossilíferos de Lágea Formosa, São Rafael-RN. Caatinga, 7:164-166.

Pansani, T.R.; Oliveira, A.M. \& Pacheco, M.L.A.F. 2016. Nova ocorrência de megafauna pleistocênica em Mato Grosso do Sul. Revista do Instituto Geológico, 37:73-85. doi:10.5935/0100$929 X .20160010$

Paula Couto, C. 1950. Peter Wilhelm Lund-Memórias sobre a Paleontologia Brasileira-Revistas e comentadas por Carlos de Paula Couto. Rio de Janeiro, Instituto Nacional do Livro, 589 p.

Paula Couto, C. 1979. Tratado de Paleomastozoologia. Rio de Janeiro, Academia Brasileira de Ciências, 590 p.

Paula Couto, C. 1980. Um tatu gigante do Pleistoceno de Santa Catarina. Anais da Academia Brasileira de Ciências, 52:527531.

Pereira, J.C. 2014. Caracterização da assembleia fossilifera do Arroio Chuí, Santa Vitória do Palmar (RS) com o auxílio SIG. Programa de Pós-Graduação em Geociências, Universidade Federal do Rio Grande do Sul, Dissertação de Mestrado, 119 p.

Pereira, J.C.; Lopes, R.P. \& Kerber, L. 2012. New remains of late Pleistocene mammals from the Chuí creek, Southern Brazil. Revista Brasileira de Paleontologia, 15:228-239. doi:10.4072/ rbp. 2012.10

Porpino, K.O.; Santos, M.F.C.F. \& Bergqvist, L.P. 2004. Registros de mamíferos fósseis no Lajedo de Soledade, Apodi, Rio Grande do Norte, Brasil. Revista Brasileira de Paleontologia, 7:349-358.

Reguero, M.; Gelfo, J.N.; López, G.M.; Bond, M.; Abello, A.; Santillana, S.N. \& Marenssi, A.A. 2014. Final Gondwana breakup: the Paleogene South American native ungulates and the demise of the South America-Antarctica land connection. Global and Planetary Change, 123:400-413. doi:10.1016/j. gloplacha.2014.07.016

Ribeiro, A.M. \& Scherer, C.S. 2009. Mamíferos do Pleistoceno do Rio Grande do Sul. In: A.M. Ribeiro; S.G. Bauermann \& C.S. Scherer (eds.) Quaternário do Rio Grande do SulIntegrando Conhecimentos, Porto Alegre, Sociedade Brasileira de Paleontologia, p. 171-191 (Monografias 1). 
Robertson, J.S. 1976. Latest Pliocene mammals from Haile XVA, Alachua County, Florida. Bulletin of the Florida Museum of Natural History, Biological Sciences, 20:111-186.

Santos, M.F.C.F.; Oliveira, L.D.D. \& Santos, C.L.A. 1990. Considerações sobre a primeira ocorrência de Pampatherium paulacoutoi Cartelle \& Bohórquez, 1985, no Rio Grande do Norte. In: CONGRESSO BRASILEIRO DE GEOLOGIA, 36, 1990. Anais, Natal, UFRN, p. 503-505.

Scillato-Yané, G.J.; Carlini, A.A.; Tonni, E.P. \& Noriega, J.J. 2005. Paleobiogeography of the late Pleistocene pampatheres of South America. Journal of South American Earth Sciences, 20:132-138. doi:10.1016/j.jsames.2005.06.012

Sellards, E.J. 1915. Chlamytherium septentrionalis, an edentate from the Pleistocene of Florida. American Journal Science, 40:139-145. doi:10.2475/ajs.s4-40.236.139

Silva, F.M.; Filgueiras, C.F.C.; Barreto, A.M.F. \& Oliveira, E.V. 2010. Mamíferos do Pleistoceno Superior de Afrânio, Pernambuco, nordeste do Brasil. Quaternary and Environmental Geosciences, 2:1-11. doi:10.5380/abequa.v2i1-2.14182

Simpson, G.G. 1930. Holmesina septentrionalis, extinct giant armadillo of Florida. American Museum Novitates, 442:1-10.

Simpson, G.G. 1932. Enamel on the teeth of an Eocene edentate. American Museum Novitates, 567:1-4.

Soliani Jr., E. 1973. Geologia da região de Santa Vitória do Palmar, RS, e a posição estratigráfica dos fósseis de mamíferos pleistocênicos. Programa de Pós-Graduação em Geociências, Universidade Federal do Rio Grande do Sul, Dissertação de Mestrado, 88 p.

Suguio, K.; Martin, L.; Bittencourt, A.C.S.P.; Dominguez, J.M.L.; Flexor, J.M. \& Azevedo, A.E.G. 1985. Flutuações do nível do mar durante o Quaternário superior ao longo do litoral brasileiro e suas implicações na sedimentação costeira. Revista Brasileira de Geociências, 15:273-286.

Tambusso, S. \& Fariña, R.A. 2015. Digital endocranial cast of Pampatherium humboldtii (Xenarthra, Cingulata) from the
Late Pleistocene of Uruguay). Swiss Journal of Palaeontology, 134:109-116. doi:10.1007/s13358-015-0070-5

Tomazelli, L.J.; Dillenburg, S.R. \& Villwock, J.A. 2000. Late Quaternary geological history of Rio Grande do Sul coastal plain, southern Brazil. Revista Brasileira de Geociências, 30:474-476.

Tomazelli, L.J. \& Villwock, J.A. 2005. Mapeamento geológico de planícies costeiras: o exemplo da costa do Rio Grande do Sul. Gravel, 3:109-115.

Ubilla, M. 1985. Mamíferos fósiles, geocronologia y paleoecologia de la Fm. Sopas (Pleistoceno sup.) del Uruguay. Ameghiniana, 22:185-196.

Ubilla, M. 1996. Paleozoología del Cuaternario Continental de la Cuenca Norte del Uruguay: biogeografía, cronología y aspectos climático-ambientales. Universidadde La República, Tese de Doutorado, $232 \mathrm{p}$.

Villwock, J.A. \& Tomazelli, L.J. 1995. Geologia Costeira do Rio Grande do Sul. Notas Técnicas, 8:1-45.

Villwock, J.A.; Tomazelli, L.J.; Loss, E.L.; Dehnhardt, E.A.; Horn, N.O.; Bachi, F.A. \& Denhardt, B.A. 1986. Geology of the Rio Grande do Sul coastal province. Quaternary of South America and Antarctic Peninsula, 4:79-97.

Winge, H. 1915. Jordgundne og nulevende Gumlere (Edentata) fra Lagoa Santa, Minas Gerais, Brasilien. Med udsigt over gumlernes indbyrdes slaegtskab. E Museo Lundii, 3:1-321.

Woodburne, M.O. 2010. The great American biotic interchange: dispersals, tectonics, climate, sea level and holding pens. Journal Mammalian Evolution, 17:245-264. doi:10.1007/s10914-0109144-8

Received in 16 February, 2018; accepted in 18 July, 2018. 